\title{
The Effects of Interrupted Enrollment on Graduation from College: Racial, Income, and Ability Differences
}

\author{
Stephen L. DesJardins \\ Associate Professor \\ Center for the Study of Higher and Postsecondary Education \\ University of Michigan \\ 2108D School of Education Building \\ 610 E. University Ave. \\ Ann Arbor, MI 48109-1259 \\ sdesj@umich.edu \\ (734) 647-1984 \\ FAX: (734) 764-2510 \\ Dennis A. Ahlburg \\ Professor \\ Industrial Relations Center \\ Carlson School of Management \\ University of Minnesota \\ 321 19th Avenue S. \\ Minneapolis, MN 55455 \\ (612) 624-6065 \\ and \\ Division of Social Statistics \\ University of Southampton \\ Highfield \\ Southampton U.K. \\ Brian P. McCall \\ Professor \\ Industrial Relations Center \\ Carlson School of Management \\ University of Minnesota \\ 321 19th Avenue S. \\ Minneapolis, MN 55455 \\ (612) 624-9521 \\ March 3, 2005 \\ Please address all correspondence to the first author.
}




\begin{abstract}
We present a multiple spells-competing risks model of stopout, dropout, reenrollment, and graduation behavior. We find that students who experience an initial stopout are more likely to experience subsequent stopouts (occurrence dependence) and be less likely to graduate. We also find evidence of the impact of the length of an initial spell on the probability of subsequent events (lagged duration dependence). We simulate the impacts of race, family income, and high school performance on student behavior and show that there are often very large differences between unadjusted rates of student outcomes and adjusted rates. Differences in student performance often ascribed to race are shown to be the result of income, age at entry, and high school performance.
\end{abstract}




\section{Introduction}

Non-continuous or interrupted enrollment (often known as "stopout" in the higher education literature) virtually assures that a student will not receive a bachelor's degree in four years. In recent years the length of time it takes to complete a bachelor's degree has garnered considerable interest among educational policy makers, the general public, and their legislative agents. Although the average time to a bachelor's degree has long been more than four years at public institutions, much of the increased interest in time to degree is due to the change in the distribution of the costs and benefits of higher education. The burden of paying for college has increasingly fallen on students and their families, as state appropriations to public institutions have fallen (in relative, and in recent years, absolute terms) and tuition rates have been increased to make up for funding shortfalls. A growing differential between the returns to the high school and college educated also makes increased time to graduation more costly for students as they delay entry into the work force.

Stopout not only affects time to degree, it may actually inhibit college completion (Authors, 2002a). To some, the fact that only about one-half of college attendees eventually graduate is widely perceived as a failure-either a failure of the student, the institution, or of the entire educational system. Some states have addressed this "failure" by tying institutional funding to graduation rates (Hebel, 1999). And recently the U.S. Department of Education has indicated a willingness to create a grant program "that would reward colleges for retaining students and graduating them on time” (Burd, 2003, p. A31). Legislators have also commented on this issue. For example, Senator Joseph Lieberman said, "colleges must do a better job of making sure more students finish the schooling they start” (Burd, 2002, p. A25). Lieberman also noted that he would like to see 90 percent of college students earn their degrees within six years.

Even though stopout is related to time to degree and degree attainment, there is a dearth of research on how non-continuous enrollment, especially multiple episodes of stopout, affects graduation chances. A National Center for Education Statistics report notes that "Little has been reported, however, on whether or not students actually do return and if so, how successful they are in completing their postsecondary education" (U.S. Department of Education, 1999, p.1). Further, we do not know if stopping out of college differentially impacts different groups of students. To address this gap in our knowledge we investigate how race/ethnicity, academic ability, and family income are related to stopout, and how the occurrence and duration of stopouts affect graduation from college. For these subgroups we are particularly interested in examining how observed aggregate or "unadjusted” graduation rates differ from “adjusted” rates. The former are the rates often produced by institutions and included in reports such as the Integrated Postsecondary Education Data System's (IPEDS) Graduation Rate Survey and the graduation reports produced by the NCAA. Adjusted rates are those produced by statistical models that control for many of the factors that are related to student departure. Astin (1993) has argued that "unadjusted” rates are often misleading and that adjusted rates are often more informative for policy.

To investigate the interrelationships among enrollment, interruptions in enrollment, and graduation we estimate a multiple-spells competing-risks model of student stopout and graduation that allows us to examine how the occurrence and reoccurrence of a spell of non-continuous enrollment is related to graduation. Our analytic approach also allows 
us to examine how the duration of a student's enrollment and stopout episodes affect their probability of graduating. In the next section we detail the specifics of our conceptual and empirical approach.

\section{Background on the Analytic Approach}

The study of the occurrence and timing of events (event history modeling) is not new in the social sciences. Event history models are often used in economics to examine unemployment behavior (Lancaster and Nickell, 1980; Moffitt, 1985; Flinn and Heckman, 1986; Meyer 1990; McCall, 1996; Choi and Shin, 2002), welfare spells (Blank, 1989; Fitzgerald, 1991; Fortin, Lacroix, and Drolet, 2002), labor stoppage and strike duration (Kennan, 1985; Gunderson and Melino, 1990), and the effect of government training programs (Ridder, 1986; Gritz, 1993; Ham and LaLonde, 1996; Eberwein, Ham, and LaLonde, 1997). This modeling technique has also been used in sociology (Rossi, Berk, and Lenihan, 1980), demography (Michael and Tuma, 1985), medical studies (Crowley and Hu, 1977), and political science (Box-Steffensmeier, 1996) but only recently has been applied to the study of educational processes (Authors, 1999, 2002a, 2002b; Löfgren and Ohlsson, 1999).

Compared to the cross-sectional designs often used to study student departure, event history modeling is a longitudinal analytic technique that is particularly well suited to study the temporal nature of student academic careers. Applying such a technique to the study of student outcomes is an innovation because cross-sectional designs, as are often used in education research, assess the substantive process being studied at a single point in time rather than over time. The technique described below, however, allows us to assess transitions from one state to the next (e.g., from being enrolled to not enrolled), and to incorporate variables that capture the changing circumstances of students as they proceed through their academic careers. It is important to study student academic careers using longitudinal data and temporal analytic techniques because cross-sectional designs contain no temporal information and therefore they cannot be used to explain how changes in independent variables affect changes in the outcome of interest (Coleman, 1981). Cross-sectional designs "are only concerned with how levels of explanatory variables ‘explain’ an outcome at a specific point in time” (Blossfeld and Rohwer, 1995, p. 10, emphasis added). There are also other limitations when researchers use crosssectional data and static methods to study temporal processes. For instance, it is very difficult to determine the direction of causality, it is hard to control for non-random processes, and reciprocal effects are hard to disentangle (see Author, 2003 for more on these limitations). Although no technique can overcome all of these problems, "crosssectional data offer the worst of all opportunities to disentangle the effects of the causal factors of interest on the outcome from other forces operating at the same time because these data are the least informative about the process of change" (Blossfeld and Rohwer, 1995, p. 7). Thus, when trying to explain change, longitudinal techniques like event history modeling are preferred to static, cross-sectional designs. In the next section we explain how event history modeling can be used to study some of the transitions that students make after they matriculate to college. 


\section{The Empirical Strategy \\ The Conceptual Model ${ }^{1}$}

We are interested in studying the transition of students across a set of discrete states. These states included being enrolled in the institution, interrupting one's enrollment in the institution (i.e., stopout), and graduation. We are particularly interested in the interval of time between entry into and exit from one state to another. In the event history literature these intervals of time are called episodes, waiting times, durations, or spells, and these terms are often used interchangeably. Whatever the nomenclature used, these terms are defined as the length of time spent in a particular state. In this study we are particularly interested in the time intervals spent enrolled and not enrolled, and how the duration in these states, and the entry into and exit from these states, affect a student's chances of graduating from a large, Research Extensive university (the University of Minnesota).

Many applications of event history modeling are restricted in that they examine only a single spell and two states (one origin and one destination state, with the relevant spell being the interval between these two states). For instance, elsewhere we estimate a single spell model of student departure and examine the duration to first stopout only (Authors, 1999). That is, the origin state is defined as "enrolled in the institution in the fall of a particular year," the destination state is the "first occurrence of non-enrollment," and the spell is the amount of time between the two. Here we relax this restriction and allow for the movement of students into and out of enrollment and stopout spells; that is, a multiple spells or repeated events approach. Further, we examine not only how the occurrence of previous spells is related to subsequent enrollment and stopout spells but also how the duration of spells affect subsequent spells. A multiple spells approach is an improvement over single spell studies because the latter do not provide information about how subsequent stopout spells are related to an initial stopout spell. For instance, students who experience a stopout may be much more likely to have a subsequent stopout, and these correlated events may depress students' chances of eventually graduating from college.

To investigate the connection between stopout and graduation, we also simultaneously model the graduation behavior of students using a "competing risks" approach. The statistical analysis of multiple stopouts (or repeated events) using a competing risks approach to account for graduation (e.g., stopout and graduation) is known in the event history literature as a "multiple spells/competing risks" model (see Lancaster, 1990 or Blossfeld and Rohwer, 1995 for additional information on these techniques). We know of no other study that has incorporated a multiple spells and competing risks approach to study student departure from college.

\section{The Empirical Specification}

Formally, the standard model to analyze the duration until an event is the (discretetime equivalent of the) proportional hazards model (see Cox, 1972; Prentice and Gloeckler, 1978; Meyer, 1986, 1990; and Han and Hausman, 1990):

$$
\begin{aligned}
& \lambda(t \mid \mathbf{x}(t), \theta) \\
& =P(T=t \mid T \geq t-1, \mathbf{x}(t), \theta) \\
& =1-\exp \left(-\exp \left(\alpha(t)+\mathbf{x}(t)^{\prime} \boldsymbol{\beta}\right) \theta\right)
\end{aligned}
$$


Many times social science researchers model only the duration until a single event occurs. For instance, elsewhere (Authors, 1999, 2002b) we estimate the probability of a first stopout only (a single spell), where $P(T=t \mid T \geq t-1, \mathbf{x}(t), \theta)$ is the conditional probability of student $i$ (not indexed for ease of exposition) stopping out in period $t$ given they have survived until $t$; $\mathrm{T}$ is a discrete random variable measuring the number of terms of enrollment until an event occurs; $\mathbf{x}(\mathrm{t})$ represents a vector of possibly time varying regressors and $\boldsymbol{\beta}$ is the (time-constant) coefficients associated with $\mathbf{x}(\mathrm{t}) ; \theta$ is a random variable of unobserved or unmeasured factors which is assumed to be independent of the regressors; and the parameter $\alpha(t)$ is a time-varying constant term that indicates the "baseline hazard" or risk of event occurrence.

The analysis of multiple durations to events of interest adds another dimension (hence the index $k$ ) to the single duration model described above, by allowing the occurrence and length of previous durations (summarized by the vector $\mathbf{h}_{t-1}$ ) to affect subsequent durations. For instance, whether students reenroll (have subsequent stopouts) is conditional on having had a prior stopout (reenrollment spell) and on the duration of these spells. This model is defined as:

$$
\begin{aligned}
& \lambda_{k}\left(t_{k} \mid \mathbf{x}\left(t_{k}\right), \mathbf{h}_{k-1,}, \theta_{k}\right) \\
& =P\left(T_{k}=t, \mid T_{k} \geq t_{k}-1, \mathbf{x}\left(t_{k}\right), \mathbf{h}_{k-1}, \theta_{k}\right) \\
& =1-\exp \left(-\exp \left(\alpha_{k}(t)+\mathbf{x}^{\prime}\left(t_{k}\right) \boldsymbol{\beta}_{k}+\mathbf{h}_{k-1}^{\prime} \boldsymbol{\delta}_{k}\right) \theta_{k}\right)
\end{aligned}
$$

where $\delta_{\mathrm{k}}$ is a vector of parameters that measure the impact of past history variables. In general, a duration may end because of different competing events. For example, an enrollment duration may end because of a stopout or graduation. Let $Y_{k}$ be a variable that equals $\mathrm{j}$ if the spell ends for reason $\mathrm{j}$. Then a multi-spells /competing risks hazard model is of the form:

$$
\begin{aligned}
& \lambda_{k}^{j}\left(t_{k} \mid \mathbf{x}_{k}\left(t_{k}\right), \mathbf{h}_{k-1}, \theta_{k}^{j}\right) \\
& =P\left(T_{k}=t_{k}, Y_{k}=j \mid T_{k} \geq t_{k}-1, \mathbf{x}_{k}\left(t_{k}\right), \mathbf{h}_{k-1}, \theta_{k}^{j}\right) \\
& =1-\exp \left(-\exp \left(\alpha_{k}\left(t_{k}\right)+\mathbf{x}_{k}{ }^{\prime}\left(t_{k}\right) \boldsymbol{\beta}_{k}^{j}+\mathbf{h}_{k-1}^{\prime} \boldsymbol{\delta}_{k}^{j}\right) \theta_{k}^{j}\right)
\end{aligned}
$$

where $\boldsymbol{\beta}_{k}^{j}$ and $\boldsymbol{\delta}_{k}^{j}$ measure the impact of $\mathbf{x}_{\mathrm{k}}(\mathrm{t})$ and $\mathbf{h}_{\mathrm{k}-1}$ on the risk that the spell ends due to the jth reason.

The structure of the enrollment and non-enrollment sequences analyzed are portrayed in Figure 1 below. Enrollment spells can end because of a stopout or graduation while non-enrollment spells can end only by re-enrollment. That is, all nonenrollment spells are single-risk duration models (and are represented by equation 2) while enrollment spells are competing risks models (with two risks and represented by equation 3). There are three enrollment and three non-enrollment spells estimated simultaneously. In the statistical model, we follow individuals either until graduation, for 19 terms (the extent of the follow-up period), or up to three enrollment and nonenrollment spells, whichever occurs first. Estimates are obtained by maximum likelihood estimation where the population distribution of the unobserved heterogeneity variables $\theta_{k}^{j}$ is assumed to be a mass point distribution with three types, which means the sample is made up of three distinct subgroups that are alike for all observed characteristics but 
have different probabilities of the relevant event occurrence (e.g., stopout, return, or graduation, depending on which model is being run) based on unobserved factors.

The empirical approach detailed above allows us to estimate three types of state dependence: occurrence dependence, duration dependence, and lagged duration dependence (Heckman and Borjas, 1980; Choi and Shin, 2002). Occurrence dependence is related to whether the number of past spells has an effect on subsequent stopouts. Duration dependence occurs when the elapsed time spent in a current spell affects the conditional probability that the spell will end before the next period. Lagged duration dependence is present when the length of previous spells has an effect on the conditional probability that a subsequent spell ends. For example, Corak (1993) found that an increase in the duration of a past insured unemployment spell had a significantly positive impact on the duration of the current insured unemployment spell.

\section{Descriptive Results}

\section{[FIGURE 1 ABOUT HERE]}

\section{Data Sources and Descriptive Statistics of the Sample}

The effective sample consists of 12,648 students who entered the University of Minnesota as first-time freshman in the fall terms of 1984, 1986, and 1991. These students were observed for more than six years (19 trimesters; six years plus one fall term). The data set was compiled by extracting information from a number of institutional databases, including admissions information, financial aid records, and student course taking and performance data. Minnesota Data Privacy Law precluded tracking students who left the University of Minnesota but enrolled at other institutions. Thus, our estimates of institutional dropout and graduation may respectively overestimate and underestimate the global rates. It is now possible to track such students through the National Student Clearing House but it was not possible when these cohorts were enrolled.

Tables 1 and 2 provide descriptive information about the three entering cohorts that comprise our sample. The cohort sizes differ because of enrollment policy decisions at the study institution. In the mid 1980's enrollments were increasing, but by the early 1990's the institution had decided to reduce undergraduate enrollments and to focus more on other policy objectives (e.g., diversity and the quality of the entering freshman classes). As a consequence, the 1991 cohort was only two-thirds the size of the earlier cohorts and was $80 \%$ white rather than about $90 \%$ white. Noteworthy is the near doubling (in percentage terms) of Asian American students from 1986 to 1991. One of the reasons for this increase is the coming of college age of the large contingent of Asian immigrant children who resided in St. Paul. The number of American Indian, Hispanic, and international students enrolled was very small in the period studied and these groups are combined in the regression analysis reported below.

\section{[TABLE 1 ABOUT HERE]}

Over the years studied, the institution attempted to improve student quality, and we observe that the average high school rank percentile increased from 68 in 1984 to about 73 in 1991. The average ACT composite scores remained relatively constant over the three cohorts, at nearly 24 . Compared to 1984, the average first-term grade point average dipped in 1986 but rose to about 2.8 by 1991 (see Table 2). 
There appears to have been a shift in the family income profiles of students over the three cohorts, with students entering in the 1991 cohort more likely to be from families with high incomes than the students who entered in either 1984 or 1986. Low-income is defined as family income less than $\$ 30,000$ per year, middle-income is between $\$ 30,000$ and $\$ 49,999$, and high-income is income of $\$ 50,000$ or more (defined in 1984 constant dollars). In 1984 about 65 (8) percent of entering students were from middle (high) income families, but by 1991 middle (high) income students accounted for 51 (19) percent of matriculants. There were also substantial differences in income by race: slightly more than 60 percent of black and Asian students were from low income households while only about 20 percent of white students were from low income households. These changes probably reflect the institutions long commitment to access for low-income students and its goal to increase quality. To increase quality, yet maintain a commitment to access for low-income students, the University appears to have substituted higher-income students for middle-income students. Regarding a move to increase quality, at least as measured by high school rank percentile, the average rose from the $68^{\text {th }}$ percentile in 1984 to the 73 rd percentile in 1991, and the variation in this indicator was also reduced.

Financial aid offered (by type of aid) is included because we believe that student decisions are made on the basis of aid offered to the student, whereas aid awarded (actually received) is the product of ex post decisions made by the student. Our contention is that aid offered is closer to the actual (unobserved) variable that affects a student's decision whether to accept an aid offer or not, thereby mitigating some of the self-selection problems that arises when using aid received as a regressor (see Authors 2002a for further discussion).

Because the characteristics of different types of financial aid vary, we expect that they will have different impacts on student stopout, return, and graduation (see Authors 2002a). Scholarships and grants do not need to be repaid so we expect them to have a larger impact than forms of aid that need to be repaid or are exchanged for labor. A scholarship is merit-based and awarded by the institution and thus may establish a gift-exchange relationship or bond of reciprocity between the student and the institution that is not produced by either Federal or state grants. Also, since most grants are means-tested, students may perceive these forms of aid as an entitlement.

Loans are likely to have the next largest impact, especially if they are subsidized. Some authors have estimated that subsidized loans have a subsidy value of one-third to one-half their face value. These estimates may, however, underestimate the subsidy value perceived by students. A recent study by the State Public Interest Research Group found that 80 percent of students surveyed underestimated the cost of their loans (Burd 2001). Kane (1999) has also argued that it is reasonable to expect an extra dollar of gift aid to be more effective than an extra dollar of loan aid in getting students to experiment with college. The student integration model of Tinto (1975) implies that work/study aid might reduce stopout and increase the chances of graduation because these subsidies tend to integrate the student into the academic and social life of the university relative to traditional oncampus or off-campus employment.

Expectations are that students with high scholastic ability would be less likely to exit before graduation (see Spady, 1970; Astin, 1993). These students may also, 
however, be more likely to receive some types of financial aid (for example, scholarships or, possibly, employment-related aid). Moreover, ability may affect a student's decision to work on campus. Since we want to isolate the effects of different types of financial aid on student departure decisions, it is important to control for factors such as student ability that may confound this relationship. We control for this potential source of omitted ability bias by including the student's overall score on the ACT college entrance examination (their "Composite” score) and their high school rank percentile. To control for performance while in college, a student's cumulative grade point average (for each term of enrollment) is also included as a time-varying covariate. Grades may be an indication of realized academic potential, whereas prematriculation ability variables may simply be measures of potential in college. Using standardized test scores to correct for omitted ability bias is common in research on education in general (see Griliches 1977; Kenny, et al. 1979; Willis and Rosen 1979; Blackburn and Neumark 1991; Grogger and Eide 1995) and in particular when examining the effects of financial aid on college attendance and completion (Stampen and Cabrera 1988; Dynarski 1999). A very low grade point average (below 2.00) could trigger academic dismissal and one might model such a rule by including a spline with a knot at 2.00 to test for this possibility. However, the exclusion GPA varies by college and level (freshman,.....senior) and there are many exceptions made to this rule, making it very difficult to accurately model this possibility. For these reasons, a spline was not included in the model. As noted above, we also include a control for unobserved and unmeasured factors. Our strategy of including multiple ability measures and a control for unobserved factors should reduce the likelihood that our financial aid effects are confounded by omitted ability bias.

Other independent variables included in the statistical models discussed below were chosen based on theoretical and institution-specific policy considerations. These include gender, age at enrollment, initial home location, the number of transfer credits a student has upon matriculation, the college the student enrolled in, and whether the student is from the Twin Cities metropolitan area, out-state Minnesota, a neighboring state, other states, or a foreign country. Minnesota and the neighboring states (and the province of Manitoba) have a long-standing bilateral tuition reciprocity agreement. Essentially, students from neighboring states receive a tuition discount compared to the typical non-resident tuition. All else equal, the "Reciprocity" variable should capture the impact of price discounting for non-resident students. ${ }^{2}$

\section{[TABLE 2 ABOUT HERE]}

\section{A Descriptive Profile of Stopout, Return, Dropout, and Graduation}

It is useful to discuss the descriptive statistics of student behavior because they are commonly used by administrators in policy discussions if not always in policy decisions. Descriptive statistics are also invariably emphasized by legislators and the media. Thus, it is informative to see if any differences exist between the descriptive statistics and the regression estimates and simulation results. If they differ, then policy errors can be made by relying solely on simple descriptive statistics.

Using stopout as an indicator of a student's propensity to disengage from the institution, which is a precursor to eventual dropout, seems reasonable given the relationship between stopout, reenrollment, dropout, and graduation (shown in Figure 1). For instance, of the effective sample $(\mathrm{N}=12,648) 71$ percent $(\mathrm{N}=9,029)$ had a spell 
of non-continuous enrollment (a "first stopout") sometime during the seven-year window of observation (summer sessions are not included in the determination of enrollment/non-enrollment). Of first stopouts, 53 percent $(\mathrm{N}=4,791)$ did not return to the institution within seven years (dubbed “Dropouts”). Of the 47 percent $(\mathrm{N}=4,238)$ of first stopouts who did reenroll ("First Returners"), 70 percent had a second stopout spell $(\mathrm{N}=2,968)$. About 43 percent of second stopouts returned $(\mathrm{N}=1,286)$ to the institution, but 832 (65 percent) of them had a third stopout episode, and 43 percent of third stopouts returned yet a third time $(\mathrm{N}=335)$.

The enrollment flow detailed in Figure 1 also demonstrates that students who stop out are less likely to graduate than students who remain continuously enrolled. Of the 4,490 total graduates (35 percent of all matriculants; which in the mid 1980's was the second lowest graduation rate in the Big Ten), 76 percent $(\mathrm{N}=3,415)$ proceeded to graduation without having a single stopout during their academic career. Figure 1 also provides an indication of the dangers of stopping out: about twelve percent $(11.9 \%)$ of students who stop out at least once graduate, 7.7 percent of those who stop out at least twice graduate, and about 4.6 percent of those who stop out three times graduate.

\section{[FIGURE 2 ABOUT HERE]}

Figure 2 provides information about the average duration of the enrollment and non-enrollment (stopout) spells of students. The mean duration of the first enrollment spell for all matriculants is about 9.1 terms (just over three academic years). If we remove students who proceed to graduation without stopping out, the average initial enrollment spell drops to about 7 terms. The average duration of the first stopout spell is about 7.2 terms, but students who do not come back to the institution ("dropouts") within the observation period are included in this statistic. When we remove dropouts, the average spell length is reduced to 2.6 terms. Students who matriculate to the institution, leave temporarily, and then return, have average second enrollment spells of a little over one academic year (3.6 terms). If these students stop out for a second time, they tend to remain stopped out for nearly five (4.8) terms. Third enrollment and stopout spells are shorter than second enrollment and second stopout episodes.

Students from different racial and ethnic groups have different propensities to stop out, reenroll, drop out, and graduate (Figure 3). African American students were more likely than their Asian American or white counterparts to stop out and less likely to return after a first or second stopout episode. African Americans also have much lower (higher) graduation (dropout) rates than their white or Asian American colleagues. The actual dropout rate for African American students is about 55 percent, whereas whites and Asians have dropout rates almost 20 points lower. Graduation rates for African Americans are about 14 percent, whereas white and Asian students have graduation rates about 2.5 times higher.

\section{[FIGURE 3 ABOUT HERE]}

Students from different family income groups also exhibit different propensities to stop out, reenroll, drop out, and graduate, but there does not appear to be as much variability as there was among racial and ethnic groups (Figure 4). Low-income students have first stopout rates about 9 (2) percent higher than their high (middle) income colleagues. Low income students are 8 percentage points less likely to return after a first stopout, and about 6 points more likely to have a second stopout than are their higher 
income counterparts. Fully 40 percent of low-income students drop out, whereas middle and high-income students have dropout rates of 38 and 35 percent, respectively. The overall graduation rate for low-income students is 31 percent, for middle-income students it is 36 percent, and for high-income students it is 41 percent. About 78 percent of high income graduates did so without stopping out, while the similar figure for their middle and low-income counterparts is about 75 percent.

\section{[FIGURE 4 ABOUT HERE]}

\section{[FIGURE 5 ABOUT HERE]}

Examining stop out, reenroll, drop out, and graduation behavior by high school performance reveals substantial variability in these outcomes (Figure 5). About a quarter of students who were in the top high school rank decile dropped out compared to 40 percent and almost 50 percent of students who scored in the 70-79 and 40-49 categories, respectively. This general pattern holds for stopout spells as well. These findings are consistent with those of Astin (1993) who found that the least well-prepared students were far more likely to drop out than the best-prepared students. Only 18 percent of students with HSR\%'s in the 40-49 range graduate, 33 percent of students with ranks in the 70-79 range, and 59 percent of top decile students receive a bachelor's degree. Of those who graduated, over 80 percent of top decile students did so without an enrollment interruption. In comparison, 66 percent of graduates in the 70-79 (40-49) HSR\% range did so without stopping out.

\section{[FIGURE 6 ABOUT HERE]}

The stopout, reenrollment, dropout, and graduation pattern of students by ACT Composite test scores are similar to those of the HSR\% groups discussed above. What is interesting to note is the high probability of repeated stopouts among students with ACT scores in the 10-14 group (Figure 6). This group has first stopout probabilities of nearly 0.90 , second stopout chances around 80 percent, and third stopout probabilities of 0.86 . Not surprisingly their graduation rate is only 11 percent whereas students in the top ACT category (30-36) graduate 56 percent of the time. One needs to be cautious about the results of the 10-14 group because of its relatively small size (451 matriculants). The reader may also notice that there is a column missing for the "Graduated-Two Stopouts" category in Figure 6. This is because none of the students who were admitted with ACT scores in the 10-14 range graduated after having two stopouts.

In summary, the simple descriptives suggest that uninterrupted spells of enrollment and graduation are positively related to being white, performing well in high school, and coming from a higher income family.

\section{Factors Related to Stopout Behavior}

The multiple spells-competing risks hazard model of equation 3 was used to estimate the risks of returning to the institution after first, second and third spells of nonenrollment or stopout (although the model simplifies to equation 2) and the risks of stopping out and graduating during the first, second, and third enrollment spells. The risk of return estimates are shown in Table 3 and the risk of stopout and graduation by enrollment spell estimates are shown in Tables 4 through 6. We do not present estimates for higher-order enrollment spells because sample sizes get quite small after third enrollment and return spells, making the estimates less precise. 
It must be remembered that these estimates are conditional and are informative only in very specific contexts. For example, if one is interested in the relative probability that an Asian American student returned given that he or she stopped out twice, then this estimate is to be found in Table 3 [coefficient is 0.333 which converts to a relative risk of $\exp (.333)=1.39]$. However, this is not equivalent to the relative probability that an Asian American student experienced two stopouts and returned. This involves the effects of race on first stopout and return, second stopout and return, and graduation. Similarly, older students are less likely to return after a first stopout than are younger students (relative risk is 0.97). However, to see the impact of age on stopout and return we would have to take into account the effect of age on the probability of first stopout (Table 4 relative risk 1.08) and the probability of return from a first stopout. Simulation is needed to answer such unconditional questions. Thus the reader interested in conditional results can consult Tables 3 through 6 to find the conditional result of specific interest.

\section{The Risks of Returning After the First Stopout}

Nonetheless, some conditional estimates are of interest because they often come up in debates about how well colleges are performing. One such estimate is the probability of returning after a first stopout and so we will briefly discuss these results. The results in Table 3 indicate that increased chances of returning after an initial stopout spell are related to higher ACT score and GPA and coming from a middle- or high-income family. For each one-point increase in the ACT Composite score, the risks of returning increase by 2.1 percent. Every full-grade increase in GPA increases the chance of return by about 25 percent.

\section{[TABLE 3 ABOUT HERE]}

No statistically significant differences were found by gender or race, although the simple descriptive statistics indicated large racial differences. What is notable is that none of the measures of financial aid that a student was receiving at the time of stopout significantly affected a student's probability of returning after an initial stopout. One might conjecture on why this is the case. Maybe students who had financial aid prior to stopping out have no expectation of receiving financial aid upon re-entry to the institution, thus aid has no effect on students' reenrollment probabilities.

With regard to lagged duration dependence, conditional on stopping out once, the risks of reenrolling increase the longer a student's initial enrollment spell. That is, students who had longer first spells of enrollment are more likely to return after a first stopout than students who had shorter initial enrollment spells. To put a magnitude on this, each additional term that a student is enrolled during their first enrollment spell increases the probability of returning after a first stopout by 3.3 percent. For each threeterm (full academic year) increase in the initial enrollment spell, one's chances of returning after a first stopout are about 10.4 percent higher [exp $(0.033 * 3)-1 * 100]$.

\section{Competing Risks Estimates for Stopout and Graduation}

Tables 4 through 6 present the competing risk estimates from our multiple spells, competing risks model. The competing risks framework allows us to account for the (possible) correlation between stopout and graduation that arises due to a correlation 
between the unobserved /unmeasured factors related to stopout and graduation. Models that fail to control for this possible dependence may provide biased and misleading results.

\section{First Enrollment Spell}

Since administrators and policy makers are concerned with what happens to students after enrollment we will briefly discuss factors related to stopout and graduation in the first enrollment spells. It is what happens in this spell that largely determines the ultimate success or failure of students. Older students, females, students who entered with transfer credits, students with higher ACT scores, and students enrolled in General College all have increased probabilities of stopping out, after controlling for other factors. Students with high academic performance in high school, Asian American students, those enrolled in the Institute of Technology, and middle- and upper-income students all have lower risks of having a first stopout episode. Every form of aid included in the model reduces the likelihood of first stopout. For instance, each $\$ 1,000$ increase in loans, merit aid, grant aid, and work/study support lowers the risks of having a first stopout by 26.2, 34.3, 21.9, and 17.8 percent. For each one-grade increase in a student's cumulative GPA, the stopout rate during the first enrollment spell decreases by over 77 percent.

\section{[TABLES 4, 5, 6 ABOUT HERE]}

Factors found to increase graduation rates during the first enrollment spell are high school rank percentile, residence outside the Twin Cities metropolitan area, transfer credits upon matriculation, gender (female), high-income, enrollment in the Institute of Technology or enrollment on the St. Paul campus (Natural Resources, Agriculture, and Human Ecology majors), and higher GPA in the first enrollment spell. So we see that higher grades and higher family income have a powerful "one-two punch" in that they both substantially lower stopout rates and increase graduation rates.

With the exception of Asian students having lower stopout risks, it is noteworthy that there are no statistically significant race effects after we control for other factors and unobservables.

In an earlier study of the 1991 cohort, the Authors (2002a) found that only work/study had a direct effect on increasing graduation. The only other beneficial effects of financial aid were found to be related to decreasing stopout. Because stopout and graduation are negatively correlated, forms of financial aid that decrease stopout can improve graduation indirectly even if they do not do so directly. In the current study, using three large cohorts rather than a single cohort, we found that most forms of financial aid decreased stopout probabilities and were also negatively related to graduation in each enrollment spell. These results seem to be counter-intuitive or ambiguous. The apparent contradiction can be explained by the following: the competing risks model is a very complicated non-linear model, where stopout and graduation are "competing" with each other. It is very difficult to interpret the partial effects when there are conflicting results like those cited above. One really needs to simulate whether the stopout or graduation effect “dominates” before one can make unambiguous statements about the effects of such results.

The importance of simulation is again seen when one looks at the partial effects of the occurrence and duration of prior events on subsequent events. The results presented 
in Tables 5 and 6 indicate that the longer a student's first stopout spell, the more likely they are to stop out again (positive coefficients on "Stopout Spell 1 Length"). As one would expect, the length of time a student remains in their first or second enrollment spell tends to increase the rate of graduating during the second or third enrollment spell. Conversely, an increase in the student's first or second enrollment spell before stopping out increases the stopout rate during the second or third enrollment spell. These seemingly incongruent results are explained by the following: in the competing risks model we really need to simulate which of these two effects dominates. That is, in such a highly complex model the partial effects are hard to interpret, therefore below we run simulations to help us better understand these results.

\section{Estimated Differences in Stopout, Return, and Graduation Probabilities Among Selected Subgroups}

The descriptive statistics cited earlier in the paper provide us with a benchmark from which to evaluate the rates produced when we control for many of the factors thought to affect stopout, reenrollment, and graduation behavior. As noted above, they often form the basis of decisions made by policymakers and the media. The multiple spells-competing risks results discussed in the previous section control for confounding as well as unobserved factors (for more on controlling for unobserved heterogeneity see Author, 2003). Below we use the model estimates to explore how stopout, reenrollment, and graduation rates depend on some important characteristics of students.

\section{Adjusted Rates of Stopout, Return and Graduation}

In general, to examine the differences in stopout, return, and graduation propensities by race, we use the statistical model to compute the various propensities when the race variables and the other variables are fixed at their actual values. Specifically, to compute the adjusted race differences between African American and white students, we first set the race variables equal to those values that represent African American students, then we use the model estimates to compute the relevant probabilities of stopout, return, or graduation for each individual in the sample (holding all other variables constant). In the third step, we then average the probabilities over all students in the sample. This process gives us an adjusted rate for each of the outcomes of interest. We repeat the three-step process noted above, but this time we set the race variables to those values that represent white students. We now have adjusted rates for whites and African American students and then use equation (4) to calculate the differences in these adjusted rates for each outcome where $D_{i}=1$ indicates white students (the baseline in this case), $D_{i}=0$ represents African Americans, and $\mathbf{x}_{i}$ represents all other regressors included in the model.

$$
\frac{1}{N} \sum_{i=1}^{N} \hat{p}\left(\text { outcome } \mid \mathbf{x}_{i}, D_{i}=1\right)-\frac{1}{N} \sum_{i=1}^{N} \hat{p}\left(\text { outcome } \mid \mathbf{x}_{i}, D_{i}=0\right)
$$

We repeat the above to calculate differences between other race/ethnic categories, and use the same analytic strategy to compare differences among family income and academic ability subgroups. Again, since we hold all other variables constant, these 
estimated differences across groups could be interpreted as “adjusted” impacts. This procedure is similar to that used by Astin (1993) to estimate adjusted retention rates.

\section{Adjusted Rates by Race}

The results displayed in Table 7 report the adjusted stopout, return, and graduation probabilities for the different race groups, holding all other variables constant. We find that for whites, the first stopout probability is 0.702. For Asian American students it is 0.670 and for African American students the probability of a first stopout is 0.729 . These adjusted probabilities are remarkably similar to the unadjusted first stopout rates (Figure 3) for whites (0.71) and Asians (0.67) but are quite different for African Americans (0.88). Thus, we see that controlling for other factors related to first stopout reduces the stopout differences between African Americans students and others because these other factors, rather than race alone, help to explain the higher stopout probability of African American students.

The probability of return to the institution after an initial stopout is slightly more than 0.5 for Asians and slightly less for whites and blacks. Conditional on return to the institution after an initial interruption in enrollment, the adjusted probability that whites will stop out for a second time is 0.832 while the probability for Asian and black students is 0.848 . Again the adjusted racial probability differences are less pronounced than the unadjusted rates displayed in Figure 3.

There is a substantial difference in the adjusted second return probabilities for Asian Americans compared to white or African American students. Asian students have conditional probabilities of second return that are about six percentage points higher than the other groups. Finally, of the very few students who experience a second stopout and third enrollment spell, their chances of stopping out yet again are very high. Since the number of students at risk of having a second stopout and subsequent re-enrollment is quite small for non-whites, one should be cautious when interpreting these findings.

Differences in the adjusted overall probabilities of graduation are quite small and much smaller than the unadjusted rates shown in Figure 3. Graduation rates for whites are about three-percentage points higher than those for African Americans and a similar amount below those of Asian American students.

We have found that most adjusted rates of stopout, return, and graduation by race are similar whereas unadjusted rates are often quite different. The upshot of this finding is that other factors correlated with race explain most of the unadjusted race differences observed in this study. What factors are correlated with race and with student outcomes? We found that relative to white students, black students are older at enrollment, have lower ACT scores and high school rank percentiles, have fewer transfer credits, and come from families with lower incomes. All of these factors are associated with higher dropout rates and lower graduation rates. To investigate the contribution of differences in family income we ran a simulation omitting family income. The 2.4 percentage point difference in graduation rates between blacks and whites increased to 3.6 percentage points. That is, there is a 50 percent increase in the "race difference" in graduation rates when differences in family income (which affect graduation) are ignored. Our point here is that differences ascribed to race are often not determined by race. Policy makers interested in understanding racial differences in stopout, dropout, and graduation behavior need to understand the relationship between race and the other factors that affect these outcomes. 


\section{[TABLE 7 ABOUT HERE]}

\section{[TABLE 8 ABOUT HERE]}

\section{Adjusted Rates by Family Income}

The computational method described by equation (4) is used to compute the adjusted rates by income reported in Table 8 . The results indicate that there are income differences in stopout, reenrollment, and graduation behavior. Even after controlling for other factors, high-income students have a probability of experiencing an initial interruption in enrollment that is four percentage points lower than students from middleincome families and seven percentage points lower than those from low-income families. These differences are smaller than the unadjusted rate differences, especially for the high income to middle income contrast. The return rate and graduation rate after return of high-income students is only slightly higher than that of other students. These small advantages of high-income students over middle- and low-income students persist in second and third stopouts.

Again we see evidence of occurrence dependence in that students who return to the institution after a previous interruption in enrollment have quite high probabilities of having a subsequent stopout.

High-income students have adjusted (unadjusted) overall graduation rates that are 7.0 (10.2) and 4.1 (5.4) percentage points higher than their low- and middle-income classmates (respectively). The entire difference in adjusted overall graduation rates is explained by differences in graduation without stopping out. Again we see the importance of controlling for factors related to graduation as they often help to explain some of the observed (but unadjusted) differences in student outcomes.

\section{[TABLE 9 ABOUT HERE]}

\section{Differences in Stopout, Return, and Graduation by High School Performance and ACT Score}

Ceteris paribus, students with higher high school rank percentiles have lower initial stopout probabilities, have higher graduation rates if they stop out once, and are less likely to stop out a second time after returning from an initial stopout than their lower achieving counterparts (see Table 9). These differences are far smaller than the unadjusted differences shown in Figure 5. Again we observe very little difference in graduation rates of students who stop out once or twice. The adjusted rate findings suggest that high school rank contributes very little to college outcomes and that it, like these outcomes, is a result of other factors. Differences between adjusted and unadjusted rates are particularly large for first stopout (lower), return and graduation (higher) for those with high school rank 40-49 and for return and graduation probabilities (lower) for students in rank 90-99.

\section{[TABLE 10 ABOUT HERE]}

Table 10 presents the result of the simulations of changes in ACT composite scores. One might expect that these results would be very similar to the high school rank percentile results. However, we observe that students who score high on the ACT test 
have higher probabilities of stopping out for a first time, and lower overall graduation rates than their lower scoring classmates. Specifically, students who have an ACT test of 35 are estimated to have initial stopout rates that are 3.1 percentage points higher than students with an ACT test score of 30. These estimated differences increase for those with lower ACT scores. For example, for students with an ACT test score of 10 the difference in first stopout probabilities increases to 16.9 percentage points. In many cases, the adjusted rate differences are much smaller than the unadjusted rate differences shown in Figure 6, and these differences are most pronounced at the extremes of the distribution. For example, the unadjusted first stopout rate for students with an ACT of 10-14 is 89 percent and an adjusted rate of 60 percent. For those with an ACT of 30-36, the unadjusted and adjusted rates are at least 20 points different (55 and at least 74 percent, respectively).

We also find what might be considered counterintuitive graduation effects. When we compare students with an ACT of 35 vs. 30, the former are predicted to have overall graduation probabilities that are 2.3 percentage points lower than the latter. When the comparison is between those within ACT score of 35 vs. 10, the estimated difference is 12.9 percentage points, indicating that high scoring students have lower predicted probabilities of graduating than very low scoring students. The unadjusted and adjusted graduation rates are also quite different, especially at the extremes. For those with an ACT of 10-14, their unadjusted graduation rate is 11 percent and their adjusted rate 44 percent. For students with an ACT of 30-36, the respective rates are 56 and 34 percent.

What is a possible explanation for these counterintuitive results? First, keep in mind that we are only analyzing graduation from a particular institution, not whether a student ultimately attains a college degree. Our results suggest that, all else equal, high scoring students are less likely to graduate from the University of Minnesota. This may occur because, other things equal, high scoring ACT students may have higher transfer rates than their lower scoring classmates because the former have more academic options than the latter. There is some evidence (DesJardins and Pontiff, 1999) that some students who leave the institution after achieving upper division status (in their junior year) are reenrolling in local private colleges. It may be that during the period under study, high scoring ACT students were more likely to take their first two or three years of college at the relatively less expensive University of Minnesota-Twin Cities campus, and then transfer to a private college (for example, Macalester College or Carleton College) from which they would obtain their degree.

\section{Potential Limitations}

This study is limited in several ways. First, since the research was conducted on a single institution, results may apply only to the study institution or be generalizable only to similar institutions (large public research universities). Second, the likelihood of self-selection in financial aid and student employment makes it difficult to determine whether the typical student receiving an offer of financial aid or work/study employment has risks different from students who do not "take-up" this type of financial assistance. We use aid offered to mitigate some of this self-selection and our method is certainly an improvement over using financial aid awarded. If we knew whether a student applied for aid, a selection correction could be attempted. At the time of data collection, however, no information was available on aid applicants 
at the study institution. As noted above, our inclusion of a number of controls for ability and performance and controls for unobserved heterogeneity should at least partly address these concerns. Third, not being able to track students outside the institution means that when we speak of "dropout" we are referring to institutional dropout, not dropout from the system of higher education in general.

A further limitation is that we have not allowed the effects of financial aid (the betas) to vary over the course of students' enrollment spells although we did allow the value of financial aid (the X's) to vary. We will relax this restriction in future work so that we can carry out policy simulations to test whether different aid packages can be used to increase time in enrollment spells, especially the initial enrollment spell that we see is so important to success in college. We will also be able to test whether aid can be packaged in ways that reduce the chances that students experience stopout spells and whether changing aid distribution can help to shorten stopout spells, which increases the probabilities of returning to college, a prerequisite to graduation. Hopefully this line of inquiry will be instructive to our colleagues and helpful to policy makers as we try to improve our understanding of the factors related to the complex process of student departure from a particular college

\section{Conclusions}

This line of research has a great deal of promise to help us improve our understanding of the process of student departure from college. Methodologically, using a multiple spells-competing risks framework that allows for unobservable determinants of events to be correlated is an innovation in helping educational researchers and policy makers learn more about the temporal dimensions of student departure. The approach allows the researcher to more completely capture the complexity of student behavior and gives the researcher and policymaker the ability to simulate the effect of particular policy variables, such as financial aid, on the full range of interrelated student behaviors, rather than just focusing on the partial effects on a single outcome. 
Substantively, we demonstrate that students who experience a stopout are more likely to experience subsequent stopouts (i.e., there is occurrence dependence), and that such a pattern of enrollment behavior is detrimental to the student's chances of graduation, especially in a timely fashion. We also find evidence of lagged duration dependence in enrollment spells. That is, as the average time in earlier enrollment spells increases, the more likely students are to graduate. Although this seems intuitive, we are able to put a magnitude on these probabilities thereby improving our understanding of the relationship between stopout and graduation. These findings indicate that institutions that are attempting to increase graduation rates should design policies to reduce stopouts. As we have shown, at the University of Minnesota (in the years studied) less than twelve percent of students who stop out eventually graduate from the institution. Initial stopouts, especially long stopouts, lead to further stopouts. This fact further underlies the need for effective strategies to reduce stopouts. Recall that the effect of earlier stopouts on later stopouts is a behavioral effect and not the result of students who are particularly "stopoutprone".

We also found that high school rank percentile, often used as a measure of student quality, has very little impact on student outcomes when other factors are controlled for, whereas another measure of student quality, ACT score, still has an independent effect. This may be because once potential and actual ability are controlled for, as measured by ACT and college grades, little ability/academic quality variation remains for high school rank percentile to "pick up.” That is, once we control for other ability/academic quality measures, there is little variation in stopout, reenrollment, and graduation outcomes to be explained by one's performance in high school. One would expect, and our research supports, that more recent measures of academic ability would be more highly related to the outcomes examined. That is, one's college grades would seem to be more highly related to success in college than how one performed in high school or how well one scored on an entrance examination. In this and other research we have conducted, we consistently find that one's performance in college, as measured by one's grades, is a very powerful indicator of timely progression toward a degree and eventual degree attainment.

Following Astin (1993), we have shown that adjusted behavioral rates are often quite different from the more commonly quoted unadjusted rates, and that the former are therefore a better guide when making policy decisions. For example, we found that race differences in stopout, return, and graduation are quite small, ceteris paribus. It is not race, per se, that explains large observed racial differences in student outcomes, rather it is other factors (e.g., lower family income) that are correlated with race. Thus, racebased policies to decrease dropout and increase graduation could be more effective if they are based on research that controls for confounding factors, rather than using racial identification as a surrogate for these factors. 


\section{References}

Allison, P. D. (1984). Event History Analysis: Regression for Longitudinal Event Data. Sage University Papers: Quantitative Applications in the Social Sciences, 07-046. Newbury Park, CA: Sage Publications.

Astin, A. (1993). “Graduation Rates May Be Misleading.” Chronicle of Higher Education 40(5), (September 22, 1993), A25.

Blackburn, McKinley, and David Neumark. "Omitted Ability Bias and the Increase in the Return to Schooling.” Journal of Labor Economics 11(3), (1991), 521-524.

Blank, Rebecca. "Analyzing the Length of Welfare Spells.” Journal of Public Economics, 39, (1989), 245:273.

Blossfeld, Hans-Peter. and Rohwer, Gotz. (1995). Techniques of Event History Modeling: New Approaches to Causal Analysis. Mahwah, NJ: Lawrence Erlbaum Associates.

Box-Steffensmeier, J.M., and Jones, B.S. (1997). Time is of the essence: Event history models in political science. American Journal of Political Science, 41: 1414-1461.

Burd, Stephen. "Lieberman Calls for More Accountability From Colleges." Chronicle of Higher Education 48(33), (April 26, 2002), A25.

Burd, Stephen. "Students Don't Realize the Extent of Their Debt, Report Warns." The Chronicle of Higher Education, (April 6, 2001), A34.

Burd, Stephen. "Education Department Wants to Create Grant Program Linked to Graduation Rates." The Chronicle of Higher Education 49(17), (January 3, 2003), A31.

Choi, HwaJung and Donggyun Shin. "Do Past Unemployment Spells Affect the Duration of Current Unemployment?” Economics Letters, 77:2, (October 2002), 157161.

Coleman, J.S. (1981). Longitudinal Data Analysis. New York: Basic Books.

Corak, M. "Is UI Addictive? Evidence from the Durations of Repeat Users." Industrial and Labor Relations Review 47 (1993), 62-72.

Cox, D. R. "Regression Models and Life-Tables (with discussion)." Journal of the Royal Statistical Society B, 34: (1972), 187-202.

Crowley, J. and Hu, M. (1977). Covariance Analysis of Heart Transplant Survival Data. Journal of the American Statistical Association, 72: 557-565. 
DesJardins, Stephen L. and Harry Pontiff (1999). Tracking Institutional Leavers: An Application. Association for Institutional Research Professional File, No. 71, Spring: 114.

DesJardins, Stephen L. (2003). “Event History Methods: Conceptual Issues and An Application to Student Departure from College.” Higher Education: Handbook of Theory and Research XVIII. New York: Agathon Press. 421-471.

DesJardins, Stephen L., Dennis Ahlburg, and Brian McCall. “An Event History Model of Student Departure.” Economics of Education Review 18, (1999), 375-390

DesJardins, Stephen L., Dennis Ahlburg, and Brian McCall. (2002a). “A Temporal Investigation of the Factors Related to Timely Degree Completion.” The Journal of Higher Education 73:5, 555-581.

DesJardins, Stephen L., Dennis Ahlburg, and Brian McCall (2002b). "Simulating the Longitudinal Effects of Changes in Financial Aid on Student Departure from College.” The Journal of Human Resources 37(3), , 651-679.

Dynarski, Susan. 1999. "Does Aid Matter? Measuring the Effects of Student Aid on College Attendance and Completion.” (Working paper \#7422). Cambridge, MA: National Bureau of Economic Research.

Eberwein, Curtis, John C. Ham, and Robert J. LaLonde. “The Impact of Being Offered and Receiving Classroom Training on the Employment Histories of Disadvantaged Women: Evidence from Experimental Data.” The Review of Economic Studies, 64:4, Special Issue: Evaluation of Training and Other Social Programmes, (October 1997), 655-682.

Fitzgerald, J. "Welfare Duration and the Marriage Market: Evidence from the Survey of Income and Program Participation.” Journal of Human Resources, 26, (1991), S45-S61.

Flinn, C. J. and James J. Heckman. “Are Unemployment and Out of the Labor Force Behaviorally Distinct Labor Force States?” Journal of Applied Econometrics, 1, (1986), 28-42.

Fortin, Bernard, Guy Lacroix and Simon Drolet. "Welfare Benefits and the Duration of Welfare Spells: Evidence from a Natural Experiment in Canada.” Journal of Public Economics, (in press, 2003).

Griliches, Zvi. “Estimating the Returns to Schooling: Some Econometric Problems.” Econometrica 45(1), (1977), 1-22.

Gritz, R. Mark. “The Impact of Training on the Frequency and Duration of Employment.” Journal of Econometrics, 57:1-3, (May-June 1993), 21-51. 
Grogger, Jeffery, and Eric Eide. "Changes in College Skills and the Rise in the College Wage Premium.” The Journal of Human Resources 30(2), (Spring 1995), 280-310.

Gunderson, Morley, and Angelo. Melino. "The Effects of Public Policy on Strike Duration.” Journal of Labor Economics 8, (July 1990), 295-317.

Ham, John C. and Robert J. LaLonde. "The Effect of Sample Selection and Initial Conditions in Duration Models: Evidence from Experimental Data on Training." Econometrica, 64:1, (January 1996), 175-205.

Han, Aaron, and Jerry Hausman. "Flexible Parametric Estimation of Duration and Competing Risk Models.” Journal of Applied Econometrics 5(1), 1990, 1-28.

Hebel, Sarah. "Virginia Board Wants to Link State Aid for Colleges to Their Performance in Key Areas.” The Chronicle of Higher Education 45, (May 28, 1999), A33.

Heckman, James, and Borjas, George. "Does Unemployment Cause Future Unemployment? Definitions, Questions, and Answers from a Continuous Time Model of Heterogeneity and State Dependence.” Economica 47, (1980), 247-283.

Kane, Thomas. 1999. The Price of Admission: Rethinking How Americans Pay for College. Washington, D.C.: Brookings Institution Press.

Kennan, J. “The Duration of Contract Strikes in U.S. Manufacturing.” Journal of Econometrics 28, (April 1985), 5-28.

Kenny, Lawrence, Lung-Fei Lee, G. S. Maddala, and Robert Trost. "Returns to Education: An Investigation of Self-Selection Bias Based on the Project Talent Data." International Economic Review 20(4), 1979, 775-789.

Lancaster, T. (1990). The Econometric Analysis of Transition Data. New York: Cambridge University Press.

Lancaster, Tony and S. J. Nickell. "The Analysis of Re-employment Probabilities for the Unemployed.” Journal of the Royal Statistical Society, Series A, 143, (1980), 141165.

Löfgren, Curt, and Henry Ohlsson. "What Determines When Undergraduates Complete Their Theses? Evidence from Two Economics Departments." Economics of Education Review, 18:1, (February 1999), 79-88.

McCall, Brian P. "Testing the Proportional Hazards Assumption in the Presence of Unmeasured Heterogeneity.” Journal of Applied Econometrics 9, (1994), 321-334. 
McCall, Brian P. 1996. "Unemployment Insurance Rules, Joblessness, and Part-Time Work.” Econometrica 64, (1996), 647-682.

Meyer, Bruce. 1986. “Semi-Parametric Estimation of Hazard Models.” M.I.T. working paper.

Meyer, Bruce. “Unemployment Insurance and Unemployment Spells.” Econometrica 58:4, (1990), 757-782.

Michael, R.T. and Tuma, N.B. (1985). Entry into parenthood by young men and women: The influence of family background. Demography, 22: 515-544.

Moffitt, R. (1985). "Unemployment Insurance and the Distribution of Unemployment Spells.” Journal of Econometrics 28, 85-101.

Prentice, Ross, and John Gloeckler. "Regression Analysis of Grouped Survival Data with Application to Breast Cancer Data.” Biometrics 34, (1978), 57-67.

Ridder, Geert. “An Event History Approach to the Evaluation of Training, Recruitment, and Employment Programs.” Journal of Applied Econometrics, 1, (1986), 109-126.

Rossi, P.H., Berk, R.A., and Lenihan, K.J. (1980). Money, Work, and Crime: Some Experimental Results. New York: Academic.

Spady, William. "Dropouts from Higher Education: An Interdisciplinary Review and Synthesis.” Interchange 1(64), 1970, 85.

Stampen, Jacob, and Alberto Cabrera. "The Targeting and Packaging of Student Aid and Its Effect on Attrition.” Economics of Education Review 7(1), (1988), 29-46.

Tinto, Vincent. "Dropout from Higher Education: A Theoretical Synthesis of Recent Research.” Review of Educational Research Vol. 45, (1975), 89-125.

U.S. Department of Education, National Center for Education Statistics. Stopouts or Stayouts? Students Who Leave College in Their First Year, NCES 1999-087, by Laura Horn. Project Officer: Dennis Carroll. Washington, DC: 1999.

Willis, Robert, and Sherwin Rosen. "Education and Self-Selection.” Journal of Political Economy, 87(3), (1979), S7-S36.

Yamaguchi, K. (1991). Event History Analysis. Applied Social Research Methods Series, Volume 28., Newbury Park, CA: Sage Publications. 
Table 1: Descriptive Statistics of Categorical Variables

\begin{tabular}{|c|c|c|c|c|c|c|}
\hline & \multicolumn{2}{|c|}{1984} & \multicolumn{2}{|c|}{1986} & \multicolumn{2}{|c|}{1991} \\
\hline & Frequency & Percent & Frequency & Percent & Frequency & Percent \\
\hline Sample Size & 4519 & 100.0 & 4931 & 100.0 & 3198 & 100.0 \\
\hline Asian Americans & 238 & 5.27 & 258 & 5.23 & 322 & 10.07 \\
\hline African Americans & 137 & 3.03 & 120 & 2.43 & 143 & 4.47 \\
\hline Latino/a & 55 & 1.22 & 50 & 1.01 & 70 & 2.19 \\
\hline American Indians & 43 & 0.95 & 54 & 1.10 & 44 & 1.38 \\
\hline Whites & 3982 & 88.12 & 4413 & 89.50 & 2564 & 80.18 \\
\hline International Students & 64 & 1.42 & 36 & 0.73 & 55 & 1.72 \\
\hline Females & 2020 & 44.70 & 2323 & 47.11 & 1515 & 47.37 \\
\hline Twin Cities Metro Area & 3197 & 70.75 & 3161 & 64.10 & 1853 & 57.94 \\
\hline Out-State Minnesota & 634 & 14.03 & 779 & 15.80 & 494 & 15.45 \\
\hline Reciprocity States & 512 & 11.33 & 637 & 12.92 & 635 & 19.86 \\
\hline Other Home Locations & 176 & 3.89 & 354 & 7.18 & 216 & 6.75 \\
\hline Institute of Technology & 896 & 19.83 & 938 & 19.02 & 562 & 17.57 \\
\hline General College & 974 & 21.55 & 802 & 16.26 & 787 & 24.61 \\
\hline Liberal Arts & 2460 & 54.44 & 2984 & 60.52 & 1687 & 52.75 \\
\hline St. Paul Campus & 189 & 4.18 & 207 & 4.20 & 162 & 5.07 \\
\hline Low Family Income & 1213 & 26.86 & 991 & 20.10 & 944 & 29.52 \\
\hline Middle Family Income & 2927 & 64.75 & 2900 & 58.81 & 1638 & 51.22 \\
\hline High Family Income & 379 & 8.39 & 1040 & 21.09 & 616 & 19.26 \\
\hline
\end{tabular}


Table 2: Descriptive Statistics of Continuous Variables

\begin{tabular}{|c|c|c|c|c|c|c|c|c|c|}
\hline & Frequency & $\begin{array}{c}1984 \\
\text { Mean }\end{array}$ & S.D. & Frequency & $\begin{array}{c}1986 \\
\text { Mean }\end{array}$ & S.D. & Frequency & $\begin{array}{c}1991 \\
\text { Mean }\end{array}$ & S.D. \\
\hline ACT Composite & 4519 & 23.67 & 4.25 & 4931 & 22.79 & 4.91 & 3198 & 23.58 & 4.16 \\
\hline High School Rank \% & 4519 & 68.12 & 24.32 & 4931 & 69.95 & 22.76 & 3198 & 72.68 & 21.71 \\
\hline Age at Enrollment & 4519 & 18.59 & 1.90 & 4931 & 18.44 & 1.66 & 3198 & 18.54 & 2.06 \\
\hline Transfer Credits & 4519 & 1.26 & 5.13 & 4931 & 3.87 & 12.71 & 3198 & 1.59 & 5.13 \\
\hline Cum GPA Term 1 & 4519 & 2.72 & 0.68 & 4931 & 2.58 & 0.88 & 3198 & 2.80 & 0.83 \\
\hline Loan Offer Term 1 & 4519 & 206.96 & 359.80 & 4931 & 240.12 & 384.02 & 3198 & 278.96 & 446.57 \\
\hline Merit Offer Term 1 & 4519 & 31.95 & 140.78 & 4931 & 95.11 & 297.15 & 3198 & 84.35 & 322.62 \\
\hline Grant Offer Term 1 & 4519 & 164.83 & 330.11 & 4931 & 224.13 & 374.54 & 3198 & 311.36 & 490.06 \\
\hline Work/Study Offer Term 1 & 4519 & 167.07 & 685.33 & 4931 & 296.22 & 855.28 & 3198 & 84.94 & 296.38 \\
\hline
\end{tabular}


Table 3: Factors Related to Returning to the Institution by Stopout Spell

\begin{tabular}{|c|c|c|c|}
\hline \multirow[b]{2}{*}{ Variable } & \multicolumn{3}{|c|}{$\begin{array}{l}\text { Stopout Spell } 1 \\
\text { Risk of Return }\end{array}$} \\
\hline & Estimate & S.E. & $\% \Delta$ \\
\hline Age at Enrollment & $-\mathbf{0 . 0 2 7}$ & 0.010 & -2.7 \\
\hline Reciprocity & -0.411 & 0.053 & -33.7 \\
\hline Out-State-MN & -0.188 & 0.050 & -17.2 \\
\hline Out-of-State & -0.517 & 0.087 & -40.4 \\
\hline ACT Composite & $\mathbf{0 . 0 2 0}$ & 0.005 & 2.1 \\
\hline High School Rank \% & -0.005 & 0.001 & -0.5 \\
\hline Transfer Credits & 0.005 & 0.001 & 0.5 \\
\hline Female & -0.019 & 0.034 & -1.9 \\
\hline Asian American & 0.125 & 0.077 & 13.4 \\
\hline African American & 0.045 & 0.095 & 4.6 \\
\hline Other Ethnicity & 0.023 & 0.096 & 2.4 \\
\hline Institute of Technology & 0.081 & 0.051 & 8.4 \\
\hline St. Paul & 0.082 & 0.080 & 8.5 \\
\hline General College & -0.328 & 0.055 & -28.0 \\
\hline Middle Income & 0.019 & 0.045 & 1.9 \\
\hline High Income & 0.050 & 0.060 & 5.2 \\
\hline 1986 Cohort & -0.025 & 0.039 & -2.5 \\
\hline 1991 Cohort & -0.075 & 0.046 & -7.2 \\
\hline Loans in Stopout Spell & -0.017 & 0.036 & -1.7 \\
\hline Merit Aid in Stopout Spell & -0.143 & 0.081 & -13.3 \\
\hline Grant Aid in Stopout Spell & -0.084 & 0.048 & -8.1 \\
\hline Work/Study in Stopout Spell & 0.071 & 0.037 & 7.3 \\
\hline Cum GPA in Stopout Spell & 0.224 & 0.030 & 25.2 \\
\hline Enroll Spell 1 Length & $\mathbf{0 . 0 3 3}$ & 0.007 & 3.3 \\
\hline Stopout Spell 1 Length & & & \\
\hline Enroll Spell 2 Length & & & \\
\hline Stopout Spell 2 Length & & & \\
\hline Enroll Spell 3 Length & & & \\
\hline
\end{tabular}

\begin{tabular}{cccccc}
\multicolumn{3}{c}{$\begin{array}{c}\text { Stopout Spell 2 } \\
\text { Risk of Return }\end{array}$} & \multicolumn{3}{c}{ Stopout Spell 3 } \\
Estimate & S.E. & \% $\boldsymbol{\Delta}$ & Estimate & S.E. & \% $\boldsymbol{\Delta}$ \\
-0.012 & 0.017 & -1.2 & -0.041 & 0.035 & -4.0 \\
$-\mathbf{0 . 4 0 1}$ & 0.107 & -33.0 & $\mathbf{- 0 . 4 6 7}$ & 0.238 & -37.3 \\
-0.061 & 0.092 & -5.9 & 0.070 & 0.191 & 7.3 \\
0.014 & 0.182 & 1.4 & -0.864 & 0.563 & -57.9 \\
0.000 & 0.009 & 0.0 & -0.004 & 0.018 & -0.4 \\
0.000 & 0.002 & 0.0 & 0.000 & 0.004 & 0.0 \\
0.000 & 0.003 & 0.0 & -0.003 & 0.006 & -0.3 \\
-0.114 & 0.063 & -10.8 & -0.213 & 0.132 & -19.2 \\
$\mathbf{0 . 3 3 3}$ & 0.139 & 39.5 & -0.281 & 0.323 & -24.5 \\
-0.008 & 0.182 & -0.8 & -0.005 & 0.389 & -0.5 \\
-0.157 & 0.199 & -14.5 & -0.173 & 0.509 & -15.9 \\
0.087 & 0.097 & 9.1 & 0.000 & 0.197 & 0.0 \\
0.083 & 0.154 & 8.6 & 0.027 & 0.346 & 2.7 \\
$\mathbf{- 0 . 2 9 1}$ & 0.100 & -25.2 & -0.264 & 0.198 & -23.2 \\
0.142 & 0.081 & 15.2 & $\mathbf{- 0 . 3 1 4}$ & 0.158 & -26.9 \\
0.140 & 0.110 & 15.0 & 0.029 & 0.209 & 2.9 \\
0.115 & 0.071 & 12.2 & -0.006 & 0.140 & -0.6 \\
-0.026 & 0.088 & -2.5 & 0.021 & 0.192 & 2.1 \\
$\mathbf{0 . 1 9 4}$ & 0.063 & 21.4 & 0.094 & 0.128 & 9.8 \\
0.251 & 0.212 & 28.5 & -0.144 & 0.814 & -13.4 \\
-0.115 & 0.093 & -10.9 & 0.118 & 0.202 & 12.5 \\
-0.184 & 0.126 & -16.8 & -0.123 & 0.965 & -11.6 \\
$\mathbf{0 . 3 5 1}$ & 0.065 & 42.1 & $\mathbf{0 . 5 0 1}$ & 0.142 & 65.1 \\
0.002 & 0.015 & 0.2 & 0.027 & 0.040 & 2.7 \\
$\mathbf{- 0 . 0 4 6}$ & 0.018 & -4.5 & -0.026 & 0.051 & -2.6 \\
0.027 & 0.018 & 2.8 & 0.065 & 0.045 & 6.8 \\
& & & -0.069 & 0.048 & -6.6 \\
& & & 0.020 & 0.056 & 2.0
\end{tabular}

Notes: Italicized variables are spell specific, e.g., Cum GPA in spell 1 (2 or 3) is used to estimate an initial (2nd or 3rd) re-enrollment.

Estimates in bold significant at $\mathrm{p}<.05$. Unobserved heterogeneity control supports 3 mass points. 
Table 4: Competing Risks Model of Stopout and Graduation For Enrollment Spell 1

\begin{tabular}{lcccccc} 
& \multicolumn{3}{c}{ Enrollment Spell 1 } \\
\multicolumn{1}{c}{ Variable } & Estimate & S.E. & $\mathbf{\%} \boldsymbol{\Delta}$ & \multicolumn{3}{c}{ Graduation Risk } \\
Age at Enrollment & $\mathbf{0 . 0 8 1}$ & 0.006 & 8.4 & 0.004 & 0.019 & 0.4 \\
Reciprocity & -0.031 & 0.046 & -3.0 & 0.136 & 0.078 & 14.6 \\
Out-State-MN & 0.003 & 0.045 & 0.3 & $\mathbf{0 . 3 0 2}$ & 0.075 & 35.3 \\
Out-of-State & 0.040 & 0.068 & 4.1 & $\mathbf{0 . 4 2 7}$ & 0.127 & 53.3 \\
ACT Composite & $\mathbf{0 . 0 4 1}$ & 0.004 & 4.2 & 0.005 & 0.009 & 0.5 \\
High School Rank \% & $\mathbf{- 0 . 0 0 4}$ & 0.001 & -0.4 & 0.004 & 0.002 & 0.4 \\
Transfer Credits & $\mathbf{0 . 0 1 6}$ & 0.001 & 1.6 & $\mathbf{0 . 0 2 0}$ & 0.002 & 2.1 \\
Female & $\mathbf{0 . 0 9 3}$ & 0.031 & 9.8 & $\mathbf{0 . 2 6 1}$ & 0.059 & 29.8 \\
Asian American & $\mathbf{- 0 . 2 2 2}$ & 0.072 & -19.9 & $\mathbf{- 0 . 2 6 0}$ & 0.122 & -22.9 \\
African American & 0.140 & 0.090 & 15.0 & -0.135 & 0.249 & -12.7 \\
Other Ethnicity & $\mathbf{0 . 1 8 3}$ & 0.082 & 20.1 & 0.282 & 0.181 & 32.6 \\
Institute of Technology & $\mathbf{- 0 . 5 4 4}$ & 0.049 & -42.0 & -0.011 & 0.073 & -1.0 \\
St. Paul & $\mathbf{- 0 . 1 5 3}$ & 0.080 & -14.2 & $\mathbf{0 . 2 5 7}$ & 0.120 & 29.3 \\
General College & $\mathbf{0 . 4 2 4}$ & 0.049 & 52.8 & $\mathbf{- 0 . 4 4 3}$ & 0.134 & -35.8 \\
Middle Income & $\mathbf{- 0 . 1 9 5}$ & 0.040 & -17.8 & -0.088 & 0.074 & -8.5 \\
High Income & $\mathbf{- 0 . 4 2 2}$ & 0.056 & -34.4 & -0.078 & 0.092 & -7.5 \\
1986 Cohort & $\mathbf{- 0 . 4 0 9}$ & 0.036 & -33.6 & $\mathbf{- 0 . 4 7 6}$ & 0.072 & -37.9 \\
1991 Cohort & $\mathbf{- 0 . 2 9 9}$ & 0.041 & -25.9 & 0.022 & 0.075 & 2.2 \\
Loans in Enroll.Spell 1 & $\mathbf{- 0 . 3 0 3}$ & 0.031 & -26.2 & $\mathbf{- 0 . 4 9 3}$ & 0.046 & -38.9 \\
Merit Aid in Enroll. Spell 1 & $\mathbf{- 0 . 4 2 1}$ & 0.060 & -34.3 & -0.110 & 0.087 & -10.4 \\
Grant Aid in Enroll. Spell 1 & $\mathbf{- 0 . 2 4 7}$ & 0.045 & -21.9 & $\mathbf{- 0 . 4 0 4}$ & 0.095 & -33.2 \\
Work/Study in Enroll. Spell 1 & $\mathbf{- 0 . 1 9 6}$ & 0.029 & -17.8 & -0.264 & 0.175 & -23.2 \\
Cum GPA in Enroll. Spell 1 & $\mathbf{- 1 . 4 6 8}$ & 0.029 & -77.0 & $\mathbf{1 . 6 3 6}$ & 0.085 & 413.6
\end{tabular}

Note: Estimates in bold significant at $\mathrm{p}<.05$. Unobserved heterogeneity control supports 3 mass points. 
Table 5: Competing Risks Model of Stopout and Graduation For Enrollment Spell 2

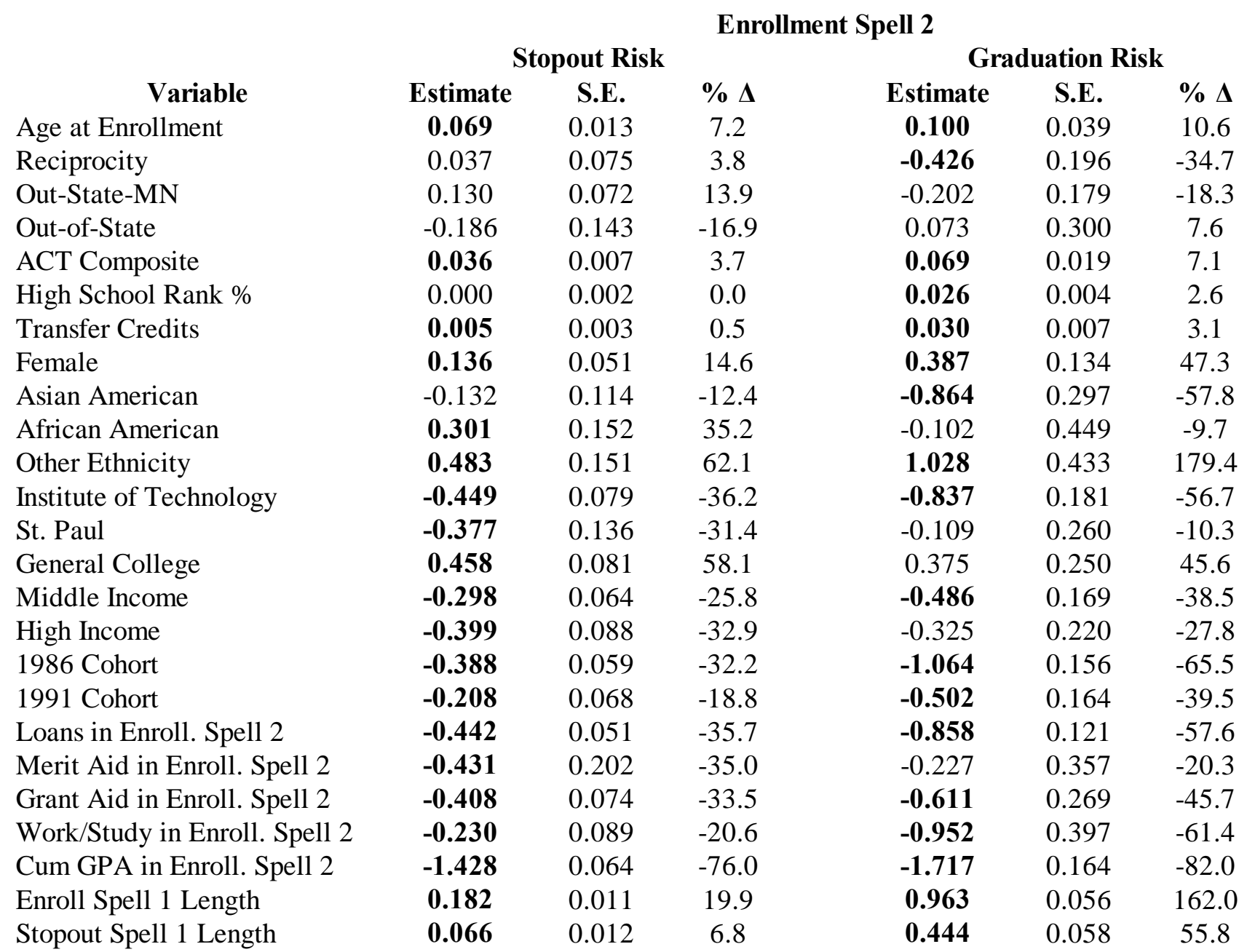

Note: Estimates in bold significant at $\mathrm{p}<.05$. Unobserved heterogeneity control supports 3 mass points. 
Table 6: Competing Risks Model of Stopout and Graduation For Enrollment Spell 3

\begin{tabular}{lcccccc} 
& \multicolumn{3}{c}{ Enrollment Spell 3 } \\
\multicolumn{1}{c}{ Variable } & Estimate & S.E. & $\mathbf{\%}$ & \multicolumn{2}{c}{ Graduation Risk } \\
Age at Enrollment & $\mathbf{0 . 1 0 8}$ & 0.028 & 11.4 & 0.099 & 0.249 & Estimate \\
Reciprocity & -0.093 & 0.193 & -8.8 & 0.926 & 0.601 & 152.6 \\
Out-State-MN & 0.165 & 0.145 & 17.9 & 0.151 & 0.756 & 16.3 \\
Out-of-State & 0.170 & 0.291 & 18.5 & 0.811 & 2.967 & 125.1 \\
ACT Composite & 0.025 & 0.014 & 2.5 & 0.067 & 0.076 & 6.9 \\
High School Rank \% & -0.001 & 0.003 & -0.1 & 0.007 & 0.015 & 0.7 \\
Transfer Credits & 0.009 & 0.005 & 0.9 & $\mathbf{0 . 1 0 3}$ & 0.033 & 10.8 \\
Female & 0.153 & 0.100 & 16.5 & 0.293 & 0.474 & 34.1 \\
Asian American & 0.033 & 0.247 & 3.3 & -0.428 & 1.306 & -34.8 \\
African American & 0.524 & 0.285 & 68.8 & $\mathbf{4 . 0 7 1}$ & 1.813 & 5762.1 \\
Other Ethnicity & -0.407 & 0.358 & -33.4 & -0.653 & 3.039 & -48.0 \\
Institute of Technology & -0.059 & 0.159 & -5.7 & -0.125 & 0.580 & -11.7 \\
St. Paul & $\mathbf{- 0 . 5 5 5}$ & 0.255 & -42.6 & -1.193 & 1.075 & -69.7 \\
General College & 0.269 & 0.153 & 30.9 & -2.057 & 1.186 & -87.2 \\
Middle Income & $\mathbf{- 0 . 2 9 1}$ & 0.119 & -25.2 & $\mathbf{- 1 . 8 0 2}$ & 0.695 & -83.5 \\
High Income & $\mathbf{- 0 . 4 3 7}$ & 0.175 & -35.4 & -1.422 & 0.880 & -75.9 \\
1986 Cohort & $\mathbf{- 0 . 4 7 9}$ & 0.125 & -38.1 & $\mathbf{- 4 . 9 2 9}$ & 1.201 & -99.3 \\
1991 Cohort & $\mathbf{- 0 . 2 8 1}$ & 0.139 & -24.5 & $\mathbf{- 1 . 4 9 0}$ & 0.615 & -77.5 \\
Loans in Enroll. Spell 3 & $\mathbf{- 0 . 5 0 4}$ & 0.093 & -39.6 & $\mathbf{- 1 . 8 0 5}$ & 0.470 & -83.6 \\
Merit Aid in Enroll. Spell 3 & -0.725 & 0.788 & -51.6 & -1.024 & 2.307 & -64.1 \\
Grant Aid in Enroll. Spell 3 & $\mathbf{- 0 . 8 9 3}$ & 0.185 & -59.1 & $\mathbf{- 2 . 9 6 1}$ & 1.254 & -94.8 \\
Work/Study in Enroll. Spell 3 & -0.462 & 0.324 & -37.0 & $\mathbf{- 4 . 1 2 5}$ & 1.922 & -98.4 \\
Cum GPA in Enroll. Spell 3 & $\mathbf{- 1 . 4 2 3}$ & 0.133 & -75.9 & $\mathbf{- 3 . 5 7 3}$ & 0.725 & -97.2 \\
Enroll Spell 1 Length & $\mathbf{0 . 2 2 7}$ & 0.028 & 25.5 & $\mathbf{1 . 9 3 5}$ & 0.305 & 592.4 \\
Stopout Spell 1 Length & $\mathbf{0 . 1 1 1}$ & 0.034 & 11.7 & $\mathbf{0 . 9 9 0}$ & 0.259 & 169.2 \\
Enroll Spell 2 Length & $\mathbf{0 . 2 2 1}$ & 0.033 & 24.8 & $\mathbf{2 . 1 2 2}$ & 0.322 & 734.6 \\
Stopout Spell 2 Length & $\mathbf{0 . 0 3 7}$ & 0.032 & 3.7 & $\mathbf{0 . 5 2 6}$ & 0.249 & 69.2
\end{tabular}

Note: Estimates in bold significant at $\mathrm{p}<.05$. Unobserved heterogeneity control supports 3 mass points. 
Table 7: Racial/Ethnic Simulations of Stopout, Return, and Graduation

\section{Outcome}

An Initial Stopout

Return After First Stopout

Graduation After First Return

Second Stopout After First Return

Return After Second Stopout

Graduation After Second Return

Third Stopout After Second Return

Graduation Without a Stopout

Graduation After One Stopout

Graduation After Two Stopouts

Overall Graduation
Adjusted Probability

Assuming All Students Are...

$\begin{array}{cccccccccc}\text { Whian } & \text { African } & \begin{array}{c}\text { Latinos } \\ \text { American } \\ \text { Whites }\end{array} & \begin{array}{c}\text { Amites vs. } \\ \text { Americans }\end{array} & \begin{array}{c}\text { Whites vs. } \\ \text { Americans }\end{array} & \begin{array}{c}\text { Whites vs. } \\ \text { Indians/Others }\end{array} & \begin{array}{c}\text { Asians } \\ \text { Asian vs. }\end{array} & \begin{array}{c}\text { Backs } \\ \text { Asian vs. }\end{array} & \begin{array}{c}\text { Bthers } \\ \text { Blacks }\end{array} & \begin{array}{c}\text { Bthers } \\ \text { Others. }\end{array} \\ 0.702 & 0.670 & 0.729 & 0.725 & 0.032 & -0.027 & -0.023 & -0.059 & -0.055 & 0.004 \\ 0.469 & 0.508 & 0.485 & 0.479 & -0.039 & -0.016 & -0.009 & 0.023 & 0.029 & 0.007 \\ 0.168 & 0.152 & 0.152 & 0.171 & 0.016 & 0.016 & -0.003 & 0.001 & -0.019 & -0.020 \\ 0.832 & 0.848 & 0.848 & 0.829 & -0.016 & -0.016 & 0.003 & -0.001 & 0.019 & 0.020 \\ 0.262 & 0.331 & 0.273 & 0.244 & -0.069 & -0.010 & 0.018 & 0.059 & 0.087 & 0.028 \\ 0.185 & 0.184 & 0.225 & 0.178 & 0.001 & -0.040 & 0.007 & -0.041 & 0.006 & 0.047 \\ 0.815 & 0.816 & 0.775 & 0.822 & -0.001 & 0.040 & -0.007 & 0.041 & -0.006 & -0.047 \\ & & & & & & & & & \\ 0.299 & 0.330 & 0.271 & 0.275 & -0.032 & 0.027 & 0.023 & 0.059 & 0.055 & -0.004 \\ 0.055 & 0.052 & 0.054 & 0.059 & 0.004 & 0.002 & -0.004 & -0.002 & -0.008 & -0.006 \\ 0.013 & 0.018 & 0.018 & 0.013 & -0.004 & -0.005 & 0.001 & -0.001 & 0.005 & 0.006 \\ 0.367 & 0.400 & 0.343 & 0.347 & -0.033 & 0.024 & 0.020 & 0.056 & 0.053 & -0.004\end{array}$

\section{Difference in}

Adjusted Probabilities 
Table 8: Family Income Simulations of Stopout, Return, and Graduation

\section{Outcome}

An Initial Stopout

Return After First Stopout

Graduation After First Return

Second Stopout After First Return

Return After Second Stopout

Graduation After Second Return

Third Stopout After Second Return

Graduation Without a Stopout

Graduation After One Stopout

Graduation After Two Stopouts

Overall Graduation
Adjusted Probability Assuming All Students Are...

$\begin{array}{ccc}\begin{array}{c}\text { High } \\ \text { Income }\end{array} & \begin{array}{c}\text { Middle } \\ \text { Income }\end{array} & \begin{array}{c}\text { Low } \\ \text { Income }\end{array} \\ 0.660 & 0.700 & 0.731 \\ 0.480 & 0.473 & 0.469 \\ 0.177 & 0.165 & 0.162 \\ 0.823 & 0.835 & 0.838 \\ 0.264 & 0.271 & 0.252 \\ 0.190 & 0.180 & 0.195 \\ 0.810 & 0.820 & 0.805 \\ & & \\ 0.340 & 0.300 & 0.269 \\ 0.056 & 0.055 & 0.056 \\ 0.013 & 0.014 & 0.014 \\ 0.409 & 0.368 & 0.339\end{array}$

Difference in Adjusted Probabilities

$\begin{array}{ccc}\begin{array}{c}\text { High vs. } \\ \text { Middle }\end{array} & \begin{array}{c}\text { High vs. } \\ \text { Low }\end{array} & \begin{array}{c}\text { Middle vs. } \\ \text { Low }\end{array} \\ -0.040 & -0.071 & -0.031 \\ 0.008 & 0.012 & 0.004 \\ 0.012 & 0.015 & 0.003 \\ -0.012 & -0.015 & -0.003 \\ -0.007 & 0.012 & 0.019 \\ 0.010 & -0.005 & -0.015 \\ -0.010 & 0.005 & 0.015 \\ & & \\ 0.040 & 0.071 & 0.031 \\ 0.002 & 0.001 & -0.001 \\ 0.000 & -0.001 & -0.001 \\ 0.041 & 0.070 & 0.029\end{array}$


Table 9: High School Performance Simulations of Stopout, Return, and Graduation

\section{Outcome}

An Initial Stopout

Return After First Stopout

Graduation After First Return

Second Stopout After First Return

Return After Second Stopout

Graduation After Second Return

Third Stopout After Second Return

Graduation Without a Stopout

Graduation After One Stopout

Graduation After Two Stopouts

Overall Graduation
Adjusted Probability When High School Rank

Percentile is Fixed at...

$\begin{array}{ccccccccccc}\mathbf{4 0} & \mathbf{5 0} & \mathbf{6 0} & \mathbf{7 0} & \mathbf{8 0} & \mathbf{9 0} & \mathbf{9 0} \text { vs. } \mathbf{8 0} & \mathbf{9 0} \text { vs. 70 } & \mathbf{9 0} \text { vs. } \mathbf{6 0} & \mathbf{9 0} \text { vs. } \mathbf{5 0} & \mathbf{9 0} \text { vs. } \mathbf{4 0} \\ 0.725 & 0.718 & 0.711 & 0.704 & 0.697 & 0.689 & -0.007 & -0.015 & -0.022 & -0.029 & -0.036 \\ 0.521 & 0.503 & 0.485 & 0.467 & 0.450 & 0.433 & -0.017 & -0.035 & -0.052 & -0.070 & -0.088 \\ 0.148 & 0.156 & 0.164 & 0.173 & 0.181 & 0.190 & 0.008 & 0.017 & 0.025 & 0.034 & 0.042 \\ 0.852 & 0.844 & 0.836 & 0.827 & 0.819 & 0.810 & -0.008 & -0.017 & -0.025 & -0.034 & -0.042 \\ 0.270 & 0.268 & 0.267 & 0.266 & 0.265 & 0.264 & -0.001 & -0.002 & -0.003 & -0.004 & -0.006 \\ 0.189 & 0.191 & 0.191 & 0.192 & 0.193 & 0.195 & 0.002 & 0.002 & 0.004 & 0.004 & 0.006 \\ 0.811 & 0.809 & 0.809 & 0.808 & 0.807 & 0.805 & -0.002 & -0.002 & -0.004 & -0.004 & -0.006 \\ & & & & & & & & & & \\ 0.275 & 0.282 & 0.289 & 0.296 & 0.304 & 0.311 & 0.007 & 0.015 & 0.022 & 0.029 & 0.036 \\ 0.056 & 0.056 & 0.057 & 0.057 & 0.057 & 0.057 & 0.000 & 0.000 & 0.000 & 0.000 & 0.001 \\ 0.016 & 0.016 & 0.015 & 0.014 & 0.013 & 0.012 & -0.001 & -0.002 & -0.002 & -0.003 & -0.004 \\ 0.347 & 0.354 & 0.360 & 0.367 & 0.373 & 0.380 & 0.006 & 0.013 & 0.020 & 0.026 & 0.033\end{array}$

Difference in Adjusted Probabilities 


\section{Table 10: College Entrance Exam Simulations of Stopout, Return, and Graduation}

\begin{tabular}{|c|c|c|c|c|c|c|c|c|c|c|c|}
\hline \multirow[b]{3}{*}{ Outcome } & \multicolumn{6}{|c|}{ Adjusted Probability When ACT Composite } & \multicolumn{5}{|c|}{ Difference in Adjusted Probabilities } \\
\hline & \multicolumn{6}{|c|}{ Score is Fixed at... } & & & & & \\
\hline & 10 & 15 & 20 & 25 & 30 & 35 & 35 vs. 30 & 35 vs. 25 & 35 vs. 20 & 35 vs. 15 & 35 vs. 10 \\
\hline An Initial Stopout & 0.604 & 0.640 & 0.675 & 0.709 & 0.742 & 0.773 & 0.031 & 0.064 & 0.098 & 0.133 & 0.169 \\
\hline Graduation After First Return & 0.162 & 0.163 & 0.163 & 0.162 & 0.161 & 0.158 & -0.003 & -0.004 & -0.005 & -0.005 & -0.004 \\
\hline Second Stopout After First Return & 0.838 & 0.837 & 0.837 & 0.838 & 0.839 & 0.842 & 0.003 & 0.004 & 0.005 & 0.005 & 0.004 \\
\hline Third Stopout After Second Return & 0.817 & 0.816 & 0.818 & 0.819 & 0.821 & 0.823 & 0.003 & 0.004 & 0.005 & 0.007 & 0.006 \\
\hline Graduation Without a Stopout & 0.396 & 0.360 & 0.325 & 0.291 & 0.258 & 0.227 & -0.031 & -0.064 & -0.098 & -0.133 & -0.169 \\
\hline Graduation After One Stopout & 0.038 & 0.044 & 0.050 & 0.056 & 0.062 & 0.068 & 0.006 & 0.012 & 0.019 & 0.025 & 0.031 \\
\hline Graduation After Two Stopouts & 0.009 & 0.010 & 0.012 & 0.014 & 0.016 & 0.018 & 0.002 & 0.004 & 0.006 & 0.008 & 0.009 \\
\hline
\end{tabular}


Figure 1

\section{Enrollment Flowchart}

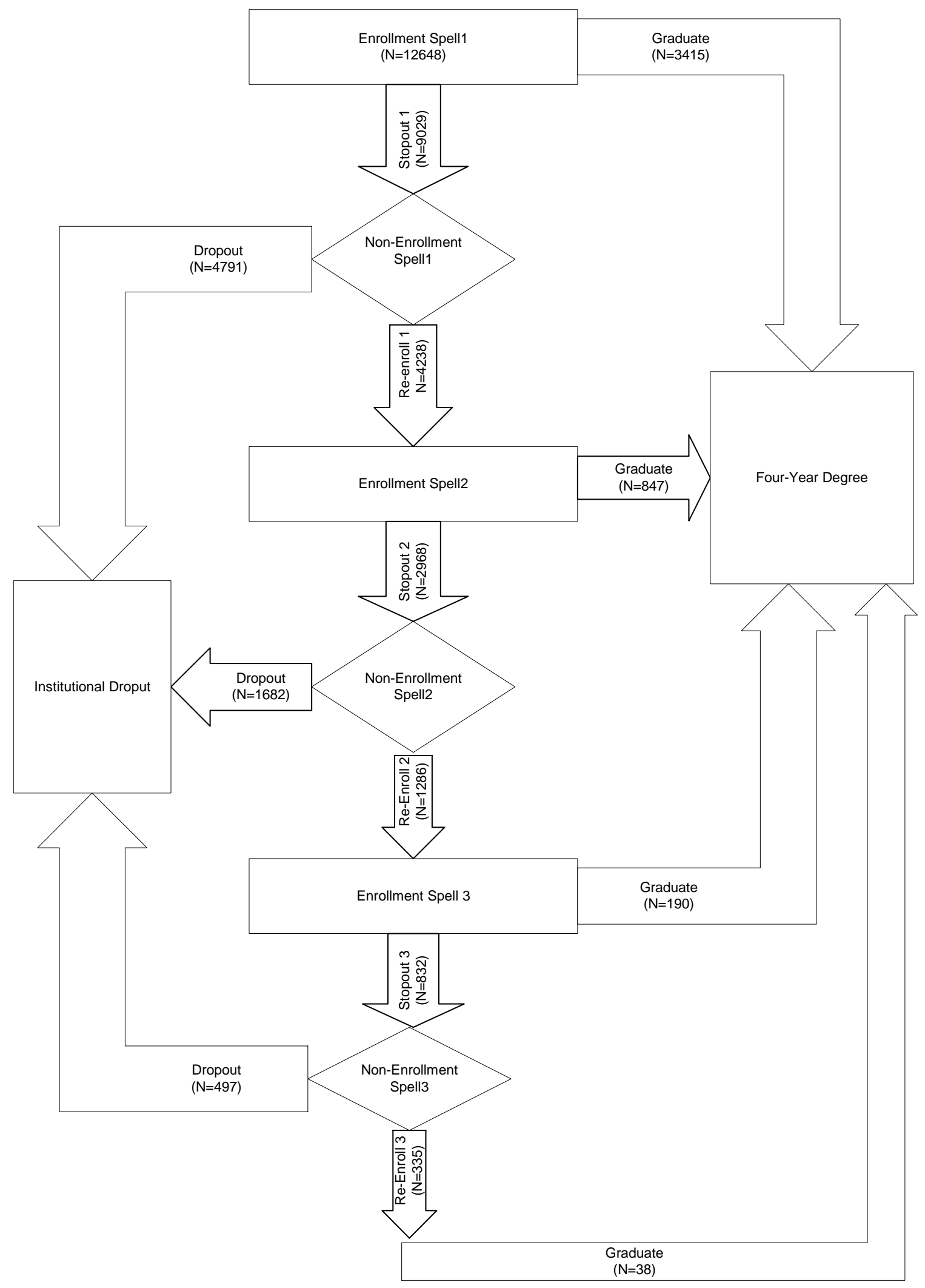


Figure 2: The Average Duration of Stopout and Enrollment Spells

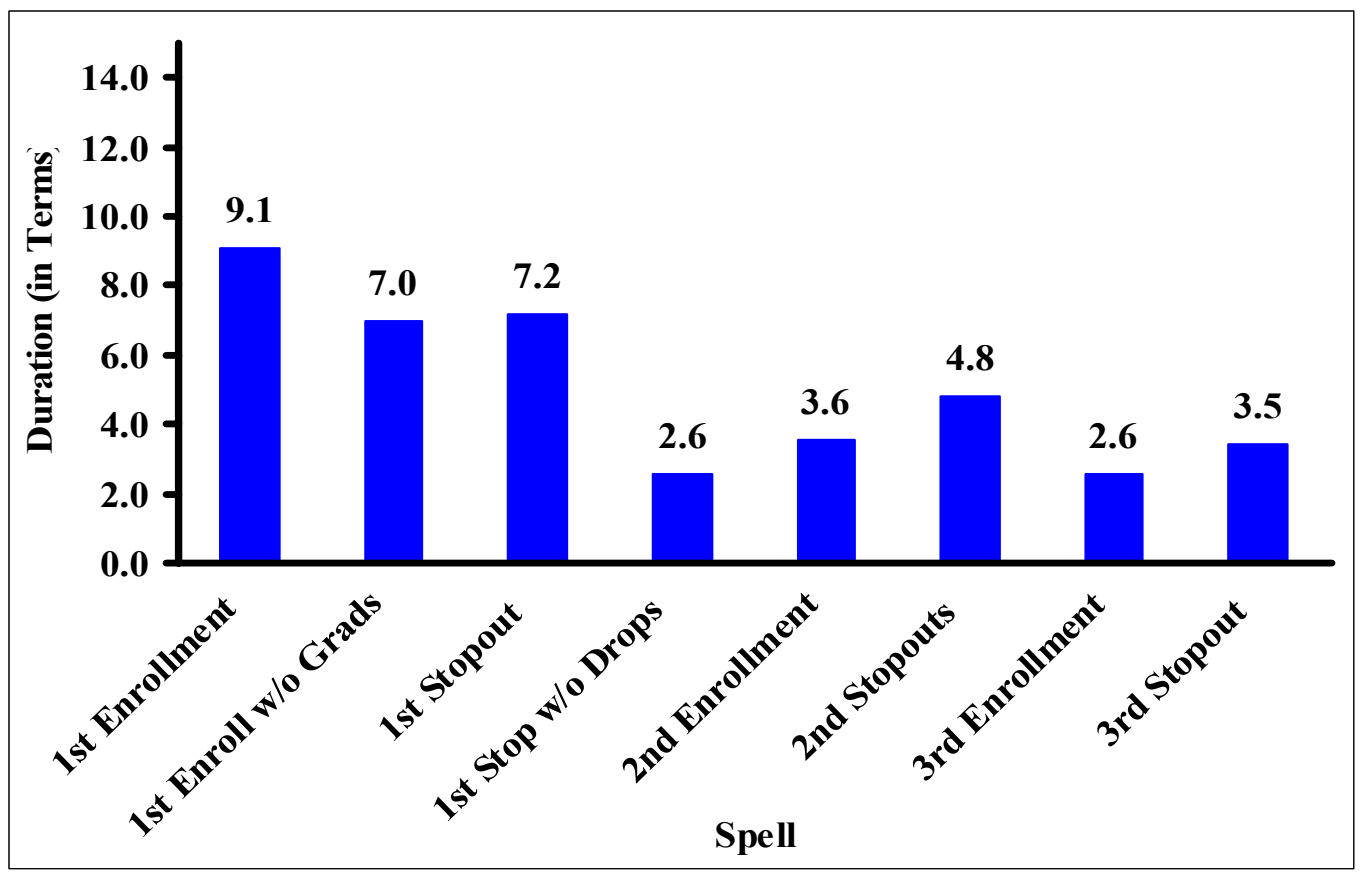


Figure 3: Differences in Stopout, Return, Dropout and Graduation by Race

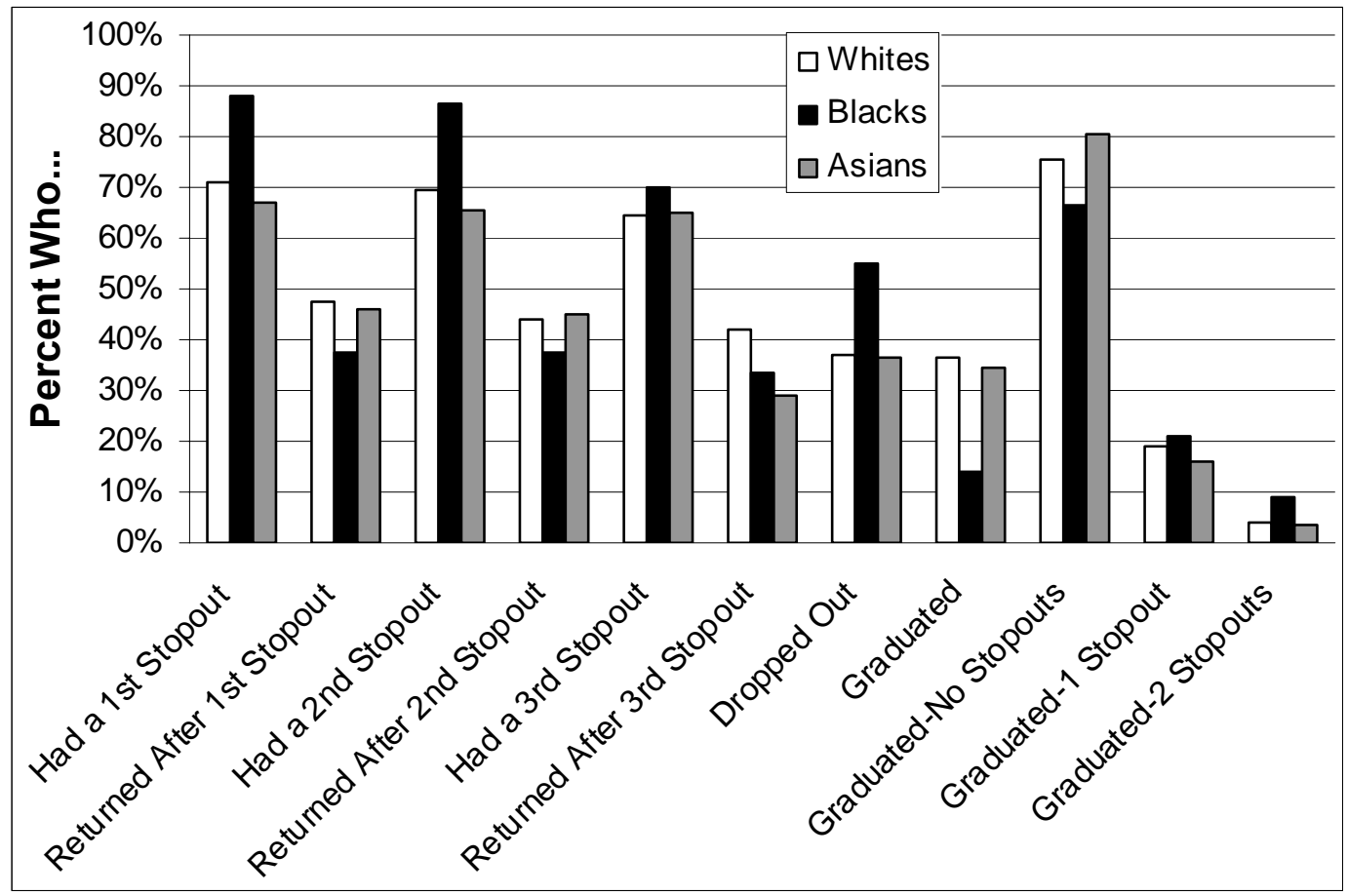


Figure 4: Income Differences in Stopout, Return, Dropout, and Graduation

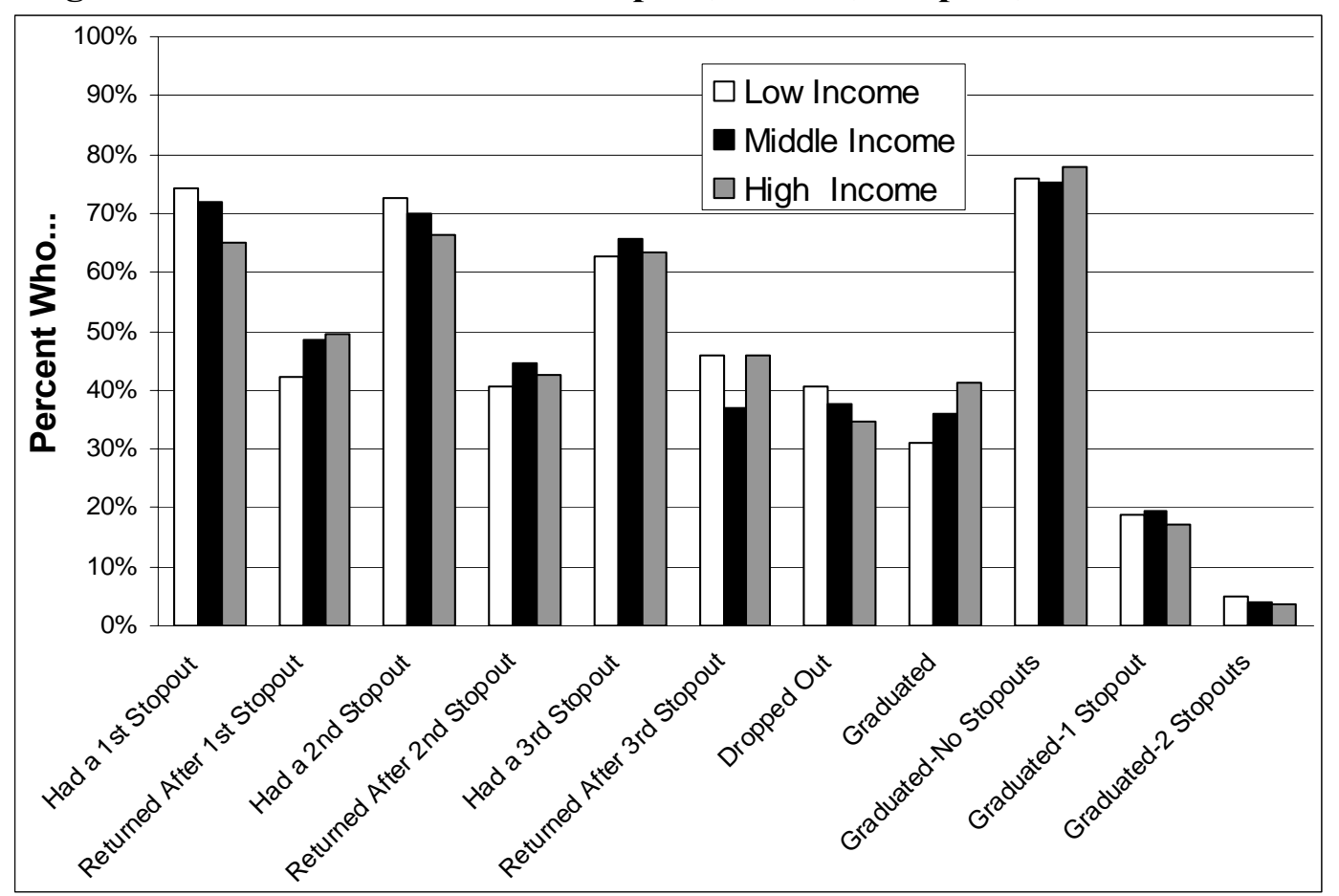


Figure 5: Differences in Stopout, Return, Dropout, and Graduation by High School Rank Percentile

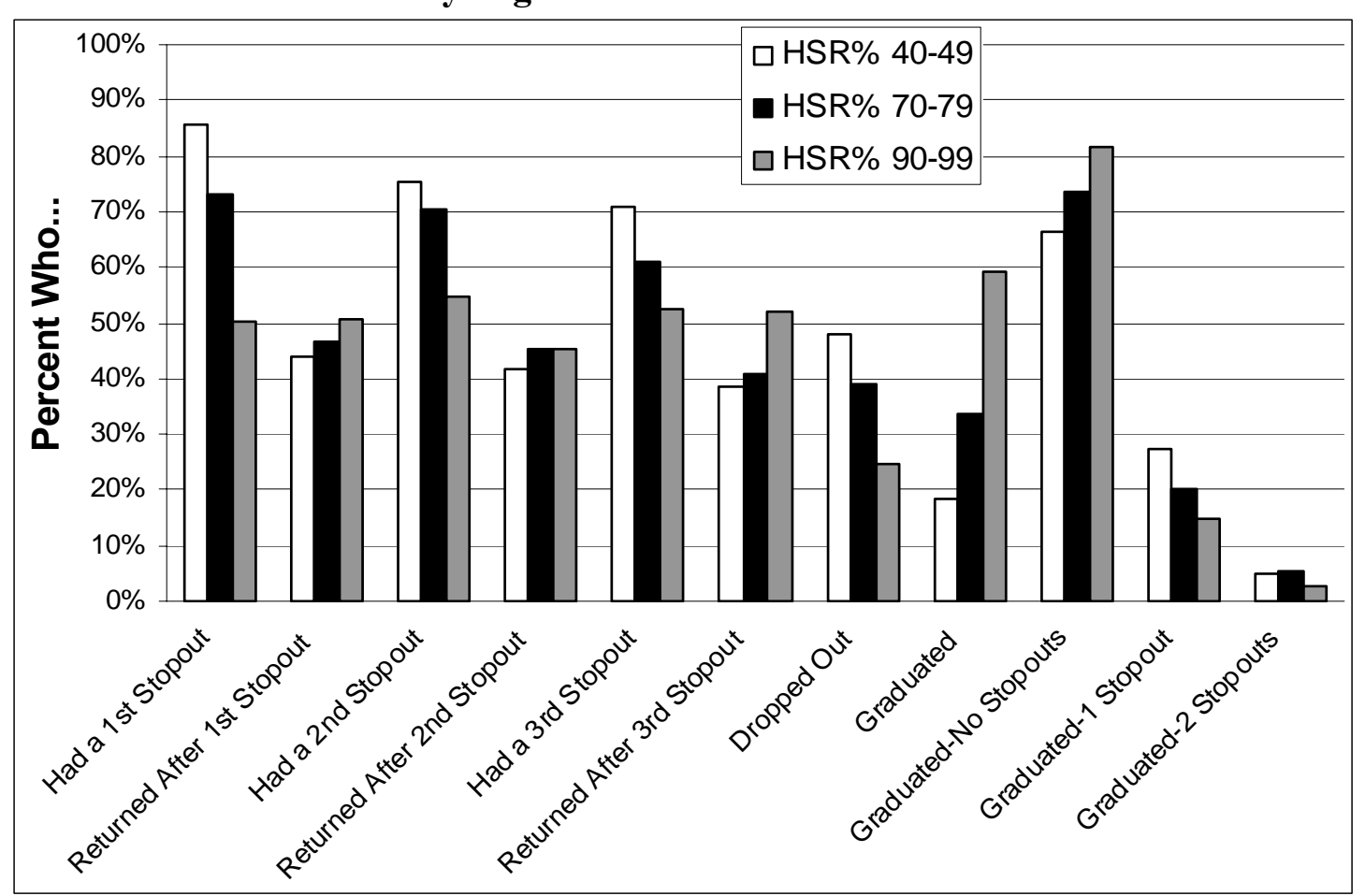


Figure 6: Differences in Stopout, Return, Dropout, and Graduation by ACT Composite Score

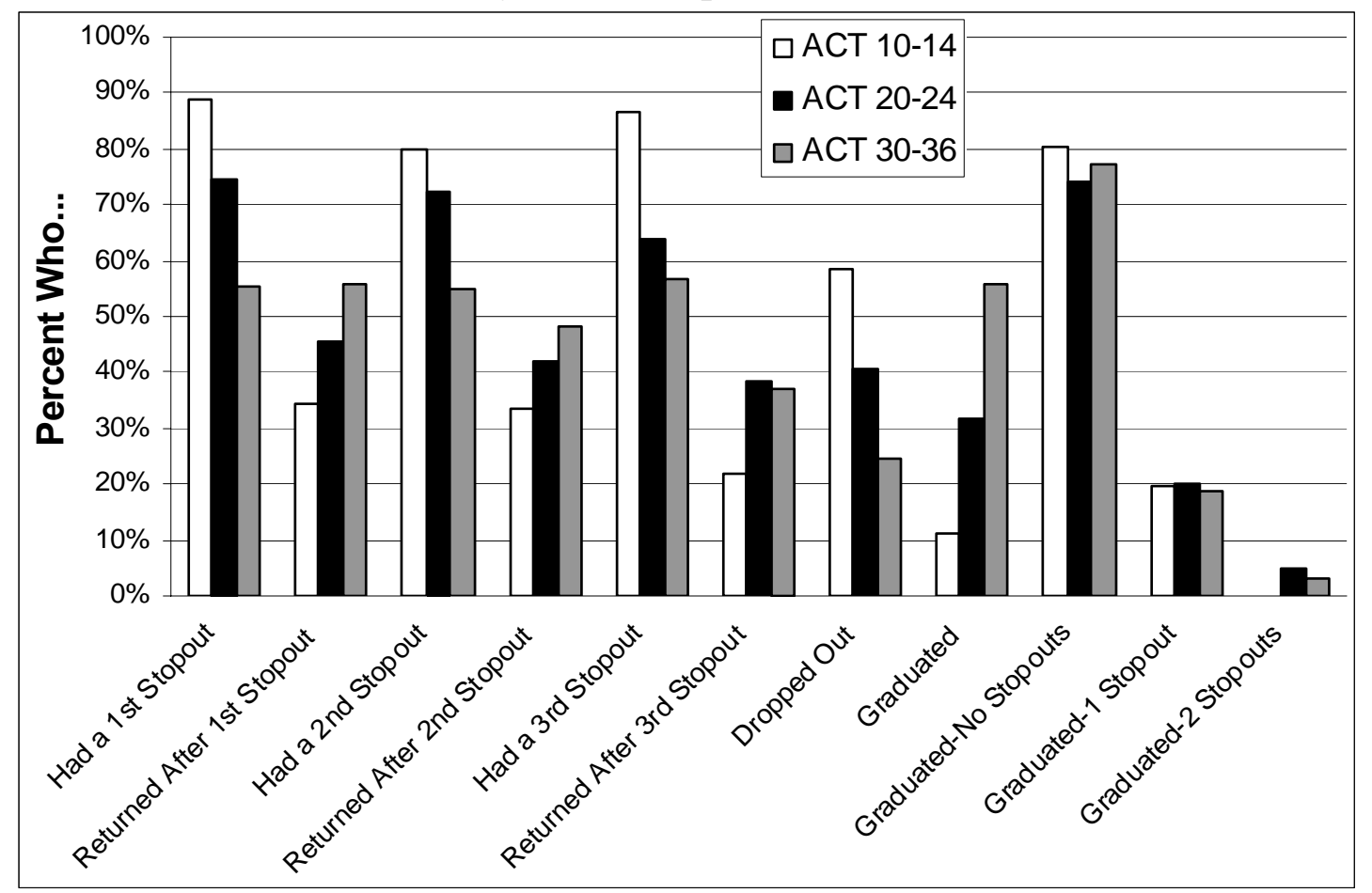


${ }^{1}$ For introductory treatments of event history modeling see Allison, 1984 or Yamaguichi, 1991. For an explanation of the conceptual theory and an application using higher education content see DesJardins, 2003.

${ }^{2}$ For the rationale for the inclusion of these regressors see Authors, 1999. 